Sérgio Bruno de Andrade Queiroz

\title{
The Impact of Private Equity Funds on the Cost of Capital of Invested Companies in Brazil
}

Dissertação de MeStrado

DePARTAMENTO DE AdMINISTRAÇÃo Programa de Pós-Graduação em Administração de Empresas 


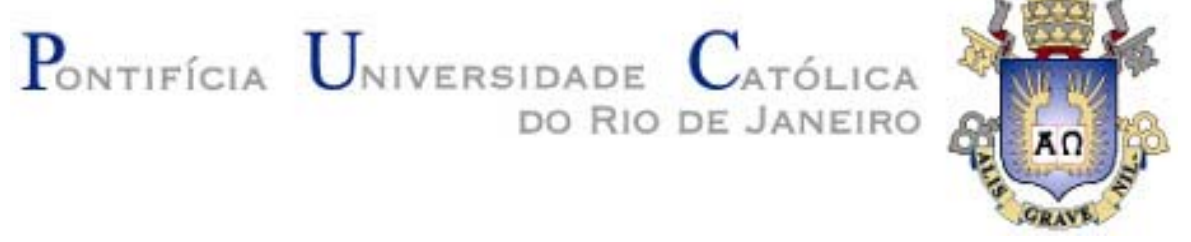

Sérgio Bruno de Andrade Queiroz Cost of Capital of Invested Companies in Brazil

\section{Dissertação de Mestrado}

Dissertation presented to the Programa de Pósgraduação em Administração de Empresas of the Departamento de Administração, PUC-Rio as partial fulfillment of the requirements for the degree of Master em Administração de Empresas.

Advisor: Prof. Antonio Carlos Figueiredo Pinto Co-Advisor: Prof. Luiz Felipe Jacques da Motta 
Sergio Bruno de Andrade Queiroz

\section{The Impact of Private Equity Funds on the Cost of Capital of Invested Companies in Brazil}

Dissertation presented to the Programa de PósGraduação of the Departamento de Administração de Empresas da PUC-Rio as partial fulfillment of the requirements for the degree of Master.

Prof. Antonio Carlos Figueiredo Pinto

Advisor

Departamento de Administração - PUC-Rio

Prof. Luiz Felipe Jacques da Motta Co-Advisor

Departamento de Administração - PUC-Rio

Prof. Marcelo Cabus Klotzle

Departamento de Administração - PUC-Rio

Prof. Martim Francisco de Oliveira e Silva Banco Nacional de Desenvolvimento Econômico e Social

Prof $^{a}$. Mônica Herz

Vice-Decana de Pós-Graduação do CCS - PUC-Rio 
All rights reserved

\section{Sérgio Bruno de Andrade Queiroz}

Graduated in Economics from Faculdade de Ciências Econômicas of Universidade Federal de Minas Gerais (FACE - UFMG) in 2008. Acted as an intern in the group of research in Innovation in Biotechnology, of Fundação Dom Cabral, as well as in the group of research in Corporate Governance, of CEPEAD - UFMG. Has been working for six years as management consultant at FALCONI - Consultants for results.

Bibliographic data

Queiroz, Sérgio Bruno de Andrade

The impact of Private Equity Funds on the cost of capital of invested companies in Brazil / Sérgio Bruno de Andrade Queiroz ; advisor: Antonio Carlos Figueiredo Pinto ; coadvisor: Luiz Felipe Jacques da Motta. - 2015.

72f. : il. ; $30 \mathrm{~cm}$

Dissertação (mestrado) - Pontifícia Universidade Católica do Rio de Janeiro, Departamento de Administração, 2015.

Inclui bibliografia

1. Administração - Teses. 2. Custo de Capital. 3. Custo Médio Ponderado de Capital. 4. Modelo de Precificação de Ativos de Capital. 5. Private Equity. I. Pinto, Antonio Carlos Figueiredo. II. Motta, Luiz Felipe Jacques da. III. Pontifícia Universidade Católica do Rio de Janeiro. Departamento de Administracão. IV. Título. 
To my Family and to Letícia, for the love and values we share, and the joy of life together. 


\section{Acknowledgements}

To my future wife, Letícia, with all my gratitude, for beginning and ending the days with me, with unconditional love and support, regardless of distance. You are a fundamental part of this work and of my life.

I am forever thankful to my parents, Cecília and Sérgio, and to my brother, Francisco, for the unconditional and constant support and for the values transmitted, which have played determinant role in this work and will forever guide me through life.

I am also thankful to my aunt Dr. Suzy de Souza Queiroz, my grandmother Wanda de Souza Queiroz, Nelson, Stela, Arthur, Roberta, Mateus and Cris, for all the support.

Thank you Andre and Toni, for sharing the hardship of Rio with me and for being there.

I am immensely thankful to Prof. Luiz Felipe Jacques da Motta, for all the teachings from day one, for the clarity of thought throughout the entire work, as well as the incentive to look for knowledge wherever possible.

To Caio Ramalho, soon to become Prof. Dr. Caio Ramalho, for the determinant support, for all the information and opinion provided.

To Prof. Antonio Carlos Figueiredo Pinto, for the determinant role in my admittance to the post grad program, for the advising and excellent classes.

To Prof. Marcelo Klotzle and Prof. Martim Francisco de Oliveira e Silva, for the significant contribution and valuable participation in the examination board.

To all my colleagues of PUC-Rio, for the days of good learning, enlightening conversations, suggestions and excellent discussions.

Thank you, Teresa Campos and Fábio Etienne, as well as IAG's office team.

To the FALCONI team, who not only were friends at work but also for supporting this work in every possible way, from conception to application of the acquired knowledge. 


\section{Abstract}

Queiroz, Sérgio Bruno de Andrade; Pinto, Antonio Carlos Figueiredo (Advisor). The Impact of Private Equity Funds on the Cost of Capital of Invested Companies in Brazil. Rio de Janeiro, 2015. 72p. Dissertação de Mestrado - Departamento de Administração, Pontifícia Universidade Católica do Rio de Janeiro.

The present study,The Impact of Private Equity Funds on the Cost of Capital of Invested Companies in Brazil, tries to combine elements from the theory of cost of capital with that of Private Equity/Venture Capital (PE/VC). Apart from performance improvements, it is expected that $\mathrm{PE} / \mathrm{VC}$ funds influence short and long term valuation of companies through their influence in the cost of capital for invested companies. The weighted average cost of capital is estimated having the cost of equity based on adjusted Capital Asset Pricing Model (CAPM)and cost of debt based on the ratio between financial expenses and average loans, debentures and short and long term financial rents. The introduction of a dummy variable to account for $\mathrm{PE} / \mathrm{VC}$ investment will indicate any impact of such participant on the cost of capital. The analysis of the impact of $\mathrm{PE} / \mathrm{VC}$ may add to the discussion on the factors that influence Brazilian companies' cost of capital.Estimated regressions show significant coefficients for most of the explanatory variables and confirm most of the expected signs. The dummy introduced to control for investment by $\mathrm{PE} / \mathrm{VC}$ funds is significant at the $10 \%$ level with a positive influence on cost of capital. Such result indicates $\mathrm{PE} / \mathrm{VC}$ funds may constitute an alternative source of financing that will influence the cost of capital on the equity share of that cost. Since studies carried out so far have done little to integrate both cost of capital and PE/VC theories, a quantitative estimate the impact of PE/VC on cost of capital will shed light on managers' decision of funding sources.

\section{Keywords}

Private Equity; Cost of Capital; WACC; CAPM 


\section{Resumo}

Queiroz, Sérgio Bruno de Andrade; Pinto, Antonio Carlos Figueiredo. O impacto de fundos de Private Equity no custo de capital de empresas brasileiras investidas. Rio de Janeiro, 2015. 72p. MSc. DissertationDepartamento de Administração, Pontifícia Universidade Católica do Rio de Janeiro.

Este trabalho, O impacto dos Fundos de Private Equity no Custo de Capital de Empresas Investidas no Brasil, tem como objetivo analisar elementos da teoria de Custo de Capital juntamente com elementos da teoria de Private Equity/Venture Capital (PE/VC). Supõe-se que fundos de PE/VC têm influência sobre o desempenho e sobre o valor de curto e longo prazo das empresas através do impacto de suas iniciativas sobre o custo de capital de empresas investidas. Neste trabalho o custo médio ponderado de capital é calculado a partir de estimativas do custo de capital próprio obtidas pelo método CAPM (Capital Aset Pricing Model) ajustado para o Brasil e a partir de estimativas do custo de dívida, baseadas na proporção representada por despesas financeiras sobre o valor médio de empréstimos, debêntures e arrendamentos de curto e longo prazo. A introdução de uma variável dummy representando o investimento de fundos de PE/VC permite identificar o impacto da atuação destes fundos no custo de capital, o que contribuirá para a discussão acerca dos fatores que influenciam o custo de capital de empresas brasileiras. As regressões estimadas sugerem que os coeficientes obtidos para grande parte das variáveis explicativas são estatisticamente significantes e confirmam a maioria dos sinais esperados. A variável dummy introduzida para controlar os efeitos dos investimentos de fundos de PE/VC mostra-se significativa ao nível de $10 \%$, com efeito positivo sobre o custo de capital.Este resultado sugere que fundos de $\mathrm{PE} / \mathrm{VC}$ podem constituir uma fonte alternativa de financiamento que influencia o custo de capital a partir do impacto sobre o custo de capital próprio. Os resultados deste trabalho contribuem para integrar as teorias de custo de capital e de Private Equity/Venture Capital, a partir de estimativas que auxiliarão gestores corporativos e da área financeira na decisão acerca da fonte de financiamento mais adequada.

\section{Palavras-chave}

Private Equity; Custo de Capital; WACC; CAPM 


\section{Summary}

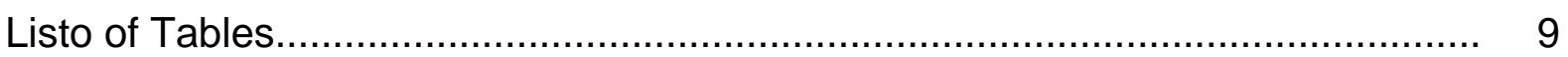

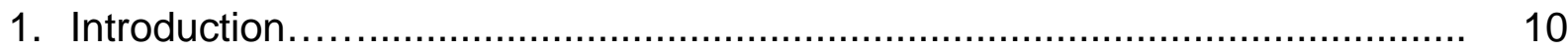

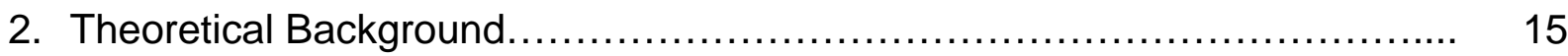

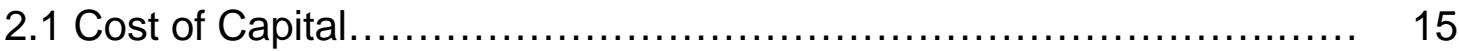

2.2 Private Equity/Venture Capital (PE/VC) ........................... 19

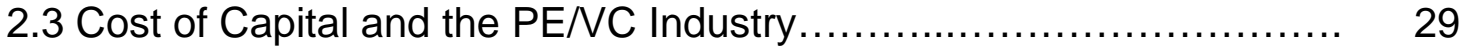

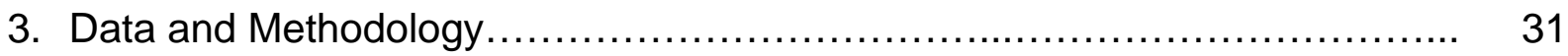

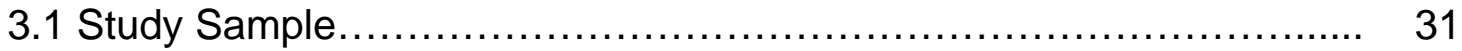

3.2 The regression model................................................ 35

3.3 Data Analysis Method .............................................. 48

4. Regression Results........................................................ 50

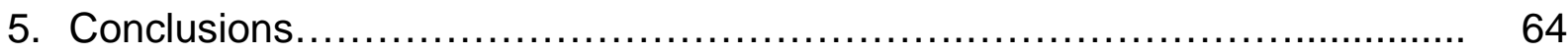

6. Opportunities for further investigation ...................................... 68

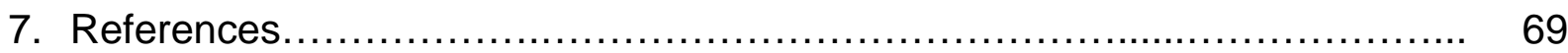




\section{List of tables}

Table 1 - Fund Manager Affiliations............................................ 21

Table 2 - Number of companies included in the sample..................... 34

Table 3 - Number of observations considered for each year by industry... $\quad 35$

Table 4 - Independent Variables description and expected signs.......... 44

Table 5 - Descriptive statistics for data in this study $\ldots \ldots \ldots \ldots \ldots \ldots \ldots \ldots . \ldots 6$

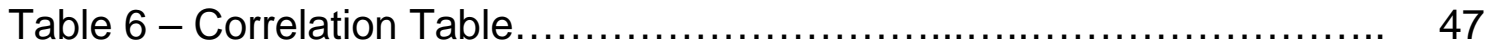

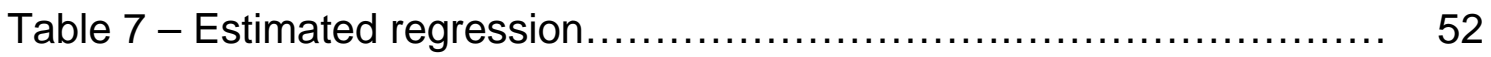

Table 8 - Estimated regression with interactive effect................. 59

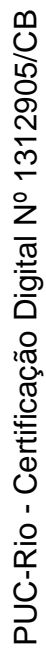

Table 9 - Estimated regression in Brazilian Real and lag ................. 62

\section{List of Figures}

Figure 1 - Initial Public Offers (IPO) per year (2004 - 2013) 


\section{Introduction}

Brazil is known for one of the highest taxation levels in the world, partly due to government political orientation and partly due to the complexity of the taxation structure. In parallel, Brazilian credit market is deeply settled on high levels of interest. Altogether, the resulting situation creates a challenging environment for companies to prosper, especially when daily drawbacks are taken into account. Management of the working capital becomes a crucial part of any company's management team and a key strategic decision for top management, especially considering daily financial commitments and future investment plans. Above all, management of the working capital has a big impact over the company's cash flow and, thus, over its valuation both on the short and long run. The involvement of Private Equity/Venture Capital (PE/VC) funds may well add pressure to the company's result, but on the other hand contribute to many aspects of the professional management of the scarce resources the company has and influence the perception that same company faces in the capital market.

Daily management of Brazilian companies encounters a number of issues that range from inadequate and insufficient logistics to lack of qualified workforce. Once taxation and interest rates are added to this equation, competitiveness becomes a difficult achievement. This complex situation bears a cost for which there are only estimates. Many of the factors that influence this cost are not managed within the companies' boundaries nor have any remedy throughout the company's operation. On the contrary, they are given by the market and it becomes a task for both strategic and tactical management to decide how they will structure the company efficiently.

Such decisions include, but are not limited to, the capital structure that will best enable the company's operation. For a given capital structure, the company will face a fixed amount of cost that can only be changed when subsequent structure adjustments are made. Modigliani and Miller (1958) state that companies will be influenced by exogenous factors which affect all companies in a given industry in the very same manner. Additionally, according to many studies (MODIGLIANI AND MILLER, 1958; BASSO et al., 2009), if there is no one optimal capital 
structure, companies are left with two possible decisions tolower their costs: improve operational efficiency and/or enable cheaper sources of capital. The first decision is a given, conditioning any company's competitiveness and determining its survival. The second decision, however, involves constant watch over arising capital market opportunities, which may include sources that become less expensive and/or the interest of a third party to invest in the company, such as $\mathrm{PE} / \mathrm{VC}$ funds.

Worldwide PE/VC industry has reached a total committed capital of US\$ 2 trillion in 2007 (RAMALHO et al., 2011), a significant amount that suggests this industry's importance. Recent changes in the Brazilian business environment have further enabled the consolidation of Brazil's PE/VC industry. According to Ramalho et al. (2011, APUD EMPEA, 2009) institutional and technical improvements have placed Brazil among the most attractive emerging economies in terms of investment opportunities, a conclusion that receives additional support by Minardi et al. (2013). Considering just Latin American countries, Brazil figures as the most attractive place in terms of $\mathrm{PE} / \mathrm{VC}$ opportunities. Additional evidence of the importance PE/VC industry has gained over the years is the increase in the amount of committed capital. From a total of US\$ 6 billion in 2004, the amount of committed capital has increased to US\$ 13 billion in 2006, US\$ 36 billion in 2009 and US\$ 100 billion in 2013 (RAMALHO et al., 2011; KPMG and ABVCAP, 2014). Recent studies estimate a $17 \%$ yearly growth rate until 2016, when total committed capital may reach 3,5\% of Brazil's GDP (MOURA, 2014). In that sense, while looking for both sources of financing and governance support, PE/VC industry cannot be overlooked.

Many authors have analyzed the influence of cost of capital on leverage and capital structure. Complementing Huang and Ritter (2009), Albanez (2012) discusses the influence of market value on leverage under the Market Timing theory. Casotti and Motta (2008) test returns right after Initial Public Offering (IPO) and over the following three years, using both the adjusted CAPM and evaluation by multiples.PE/VC studies, on the other hand, have in general focused on the performance improvements of invested companies (GORMAN; 
SAHLMAN, 1987; BRAV; GOMPERS, 1997; HELLMANN; PURI, 2002;GIOIELLI, 2008; TESTA; LIMA, 2013; BASTOS, 2014).

Apart from performance improvements, it is expected that $\mathrm{PE} / \mathrm{VC}$ funds influence short and long term valuation of companies through their influence in the cost of capital for invested companies. In that sense, what is the magnitude of this influence on cost of capital? The answer for this question in the Brazilian market may reinforce the important role $\mathrm{PE} / \mathrm{VC}$ plays in the capital market and provide an alternative for privately held companies in their look for sources of capital, among other managerial benefits.

The hypothesis under analysis is that invested companies face lower overall cost of capital. Given the improvement on Corporate Governance mechanisms, increase in financial reporting standardization and the reduction in Information Asymmetry (PHAM et al., 2007; GIOIELLI, 2007), a firm's manager could expect financial institutions to lower the interest rates charged for any given loan. Cost of equity, on the contrary, may increase due to higher rates of return targeted by PE/VC funds (TESTA; LIMA, 2013; GOMPERS et al., 2014; BASTOS, 2014). Such is not a straight forward consequence, since it could be expected that governance improvements introduced by $\mathrm{PE} / \mathrm{VC}$ could reduce overall costs with an increase in efficiency. However, the decision to invest in a specific company bears an opportunity cost that must be compensated.

The analysis of the impact of PE/VC investments on invested companies' cost of capital may add to the discussion on the factors that influence Brazilian companies' cost of capital. In that sense results may corroborate gains of efficiency and present some quantitative measures of the impact of $\mathrm{PE} / \mathrm{VC}$ funds on cost of capital (PHAM et al., 2007).Estimates of the cost of capital are based on the Weighted Average Cost of Capital, cost of equity is based on CAPM model, adjusted for the Brazilian market and cost of debt is estimated from debt and financial expenses information. A dummy variable is introduced in the model to account for investment by $\mathrm{PE} / \mathrm{VC}$ funds.

This study may contribute to integrate cost of capital theory with that of PE/VC. For the financial manager, it may improve knowledge on alternative sources of 
capital that may contribute to creating value, be it through management improvement, reduction of cost of capital and/or improvement of the relationship with financial institutions.

The studies carried out so far have limited the choice of variables within the cause-effect relationship of the predominant theory. Hence, cost of capital and $\mathrm{PE} / \mathrm{VC}$ studies have analyzed only variables within their limited frameworks. In that sense, a wider view of the possibilities and consequences of the managers' decision may benefit from the development of an integrated analytical structure. The corporation finance specialist concerned with short term choices and long term consequences may find it helpful to use a tool that enables a wider view.

The effort to quantitatively estimate the impact of $\mathrm{PE} / \mathrm{VC}$ on cost of capital will aid managers on their decision of funding sources. Many studies have tried to estimate the impact of market conditions on cost of capital. A considerable number of studies has estimated the impact of Corporate Governance improvement on a firm's efficiency, as well as identified the role of PE/VC managers regarding invested companies. However, there is little evidence of attempts to integrate any of these theories. Since Brazilian capital market is still highly concentrated on a group of big companies and there are limited financing options at a fair cost, this study could contribute to increase the knowledge on the benefits of external investment on firms' operational and financial efficiency.

Apart from adding to financial decision making, this study may reinforce the powerful long term contribution $\mathrm{PE} / \mathrm{VC}$ has on the growth capacity of firms and on the economy overall. Specifically regarding the Brazilian environment, the study may contribute to foster $\mathrm{PE} / \mathrm{VC}$ participation as a solid funding option which adds a great deal of value to growing businesses.

This study is organized in five sections, apart from this introduction. Section 2 discusses the studies carried out on cost of capital and PE/VC. Section 3 presents the procedures followed in order to obtain the information and analyze it. The description of the sources used, the variables introduced in the model as well as the model itself are included in this section. Section 4 presents the results of the estimated regression along with a discussion on the signs obtained and their 
possible significance. Results are consolidated and confronted with previous theoretical background in section 5. Finally, section 6 presents some additional opportunities for future investigation. 


\section{Theoretical Background}

\subsection{Cost of Capital}

Many authors have analyzed the influence of cost of capital on leverage and capital structure. For a given capital structure, the company will face a fixed amount of cost that can only be changed when subsequent structure adjustments are made. Modigliani and Miller (1958) state that companies will be influenced by exogenous factors which affect all companies in a given industry in the same manner.Auerbach (1984) suggests that if firms face different costs for each source of financing, they will first use the least expensive source, using more expensive ones if the opportunity proves itself beneficial. The authors use panel data on 274 NYSE listed companies to formulate a model of investment and financial behavior based on the maximization of the stockholder utility in the presence of constraints. His model accounts for differences of taxation regimes, following the proportion of different types of shareholders each firm has, while measuring the impact of each financial structure on the return.His results suggest new share issues present a significantly higher cost, as compared to debt or retention. In that sense, firms will issue new shares as a last option.Interestingly, firms keep distributing dividends even when new shares are issued or new debt is acquired, contradicting the idea that they would benefit from retention for new investments.

Similar results were obtained by Lee et al. (1996). Using nominal gross proceeds from US security offerings from September 1990 to December 1994, these authors state that each source of capital will present a different percentage of cost. Their work focuses on identifying real costs of four different sources of capital. The costs are calculated as the percentage that gross spreads and other direct expenses represent in comparison to total proceeds. They estimated that IPO's present the highest costs followed by SEO's, convertible bonds and straight bonds. Additionally, companies with investment grade face lower costs, which can also be attained through economies of scale in every source of capital.

Also studying capital structure decision, Huang and Ritter (2009) examine how a variation in cost of equity may affect leverage and how fast any adjustment occurs. If such speed is not high, firms' current financing decision will influence 
their cost for many years, reducing not only returns but also market value. On the contrary, if such speed is high, capital structure may be rapidly adjusted so as to eliminate the effect of high costs of capital on return and value, thus reducing the importance of the Market Timing theory. Using the concept of Equity Risk Premium (ERP) their study makes a good contribution to the relationship between cost of equity and securities issuance. These authors explore the role of changing market conditions in firms' financial behavior and observed current capital structures. They observe that firms fund a large portion of their financing deficit with equity when its relative cost is low. Also, effect of ERP variation is long lasting on capital structure: increase in leverage is significantly higher when historical ERP is higher. The propensity to borrow also increases according to ERP variations. Combined with market conditions, the effect persists for some time, reducing significantly after 8 years.

Albanez (2012) discusses the influence of market value on leverage under the Market Timing theory, which states that companies will issue more shares whenever market values are higher than book values. Apart from estimating the cost of capital from both private and financial sources, the study investigates opportunistic behavior when Brazilian publicly traded companies search for sources of financing.

The study adds to Huang and Ritter (2009) a proxy for cost of debt, linked to the company's rating, as a proxy to measure an ex-ante cost of debt, as opposed to the information taken from balance sheets and income statements that account for expost cost. Two samples are analyzed separately, one of them controlling for companies' rating (attributed by one of the three main Rating Agencies, namely Standard and Poor's, Moody's and Fitch). Using the income statements from 313 publicly traded Brazilian companies from a period of five years after the IPO, her analysis tries to corroborate the Market Timing theory and its effects on capital structure. It is expected that once market pricing movements not always correspond to fundamentals, managers have a great incentive to benefit from these pricing mistakes and fund their investments by issuing new shares. Parameters demonstrate that there is a significant influence of cost of capital from different sources on capital structure. Different cost of capital for each source will not only 
influence the source chosen by managers, but also the amount of each type. It will also allow for adjustments when market conditions prove favorable to reduce the amount of debt and increase the amount of equity. Albanez (2012) demonstrates that higher ratings enable lower levels of interest rates and finds that the companies' leverage is positively correlated with the cost of equity. She concludes that Market Timing influences financing decisions and thus the capital structure of Brazilian companies, although they tend to work more often with loans and issue shares a smaller numbers of times, when compared to foreign markets.

A number of methods for estimating cost of capital are available, some of which trying to identify the components of Weighted Average Cost of Capita (WACC)used both internally and for information disclosure (BRUNER et al., 1998; GARBRECHT, 2013;OLIVEIRA; MARTELANC, 2013). Regarding cost of equity, practitioners rely on alternative methods, given that information on returns on such type of capital is not easily available. With regards to the cost of capital estimating method, Bruner et al. (1998) carried out a telephone survey with 27 leading practitioners to obtain a descriptive method. An overall high alignment of practices can be found among firms, most of which use financial economic models instead of rules of thumb. Authors conclude that Discounted Cash Flow is dominant technique for investment evaluation. Using WACC as the discount rate, weights are based on market rather than book values and CAPM is the dominant method for cost of equity. However, CAPM variables are not calculated in the same way, with the predominance of the ten year T-Bond as the risk-free rate. A significant amount of practitioners rely on beta estimates from published sources and many surveyed use other different sources. Regarding Equity market risk premium, all surveyed rely on historical information to estimate future spreads, with quite as many respondents relying on arithmetic versus geometric average for both returns and T-bills or T-Bonds. Divergence is also found among estimates initial period and total length of time considered.Another result indicates that cost of capital estimation by M\&A practitioners offer higher estimates, on average, a result already suggested by Sahlman (1990).

According to Casottiand Motta (2008), the use of CAPM as the main component for evaluating companies from emerging economies requires a series of simple 
adjustments to account for small participation of the stock market in the economy, concentration of operations on a few companies, higher sovereign risks and the determinant role that foreign investors play on Brazilian IPO's. The use of comparable betas is also complicated since there are very few comparable companies in emerging markets, raising the need to use international comparable betas. In that sense, the so called Adjusted CAPM, or Goldman Model, denominated in US Dollars, must include the risk free rate from the NorthAmerican economy, the difference between American and Brazilian yield to maturity long term rates, representing the country's risk premium, betas from comparable north-American companies and the expected return from a northAmerican market index.

According to Cunha et al. (2013), decision over which type of WACC calculation to use influences valuation process. Authors highlight problems that arise when instead of market values, estimates use book values, which will influence the weight each source of capital will have on final cost estimate. The Securities and Exchange Commission of Brazil (CVM) instructions require a valuation process using Discounted Cash Flow method, with market values used to estimate the discount rate. The authors find that $79 \%$ of reports used WACC as discount estimate, but only $5 \%$ of them with market values. The majority used book values or applied an optimum capital structure approach, which may have affected the companies' value estimates and subsequent transactions.

Albanez (2012) adds to the discussion, introducing different proxies for each kind of cost included in cost of capital estimation. In order to study the relationship between cost of capital and financing decisions, she sets two variations of leverage as the dependent variable and four proxies for cost of equity and two proxies for cost of debt as the independent variables. All proxies for cost of equity were based on CAPM model, adjusted for the Brazilian market. For the cost of debt, two variations were used in the analysis. The first of them measures the relationship between the amount of financial expenses net of taxes and average loans, debentures and short and long term financial rents registered in Balance Sheets. The second proxy for cost of debt was based on end of the fiscal year long term credit ratings and their respective interest rates. 
Argolo et al. (2012) investigate whether estimates obtained with Fama and French Three Factor cost of capital (Market Risk Premium, High Value stock Premium, Low value Stocks Premium) apply to Brazil. Using stock prices for Brazilian publicly traded companies from 1995 to 2007, they test two additional factors. Although the power of the model increases, it does so marginally and only the beta estimate for traditional CAPM model proves consistent throughout the entire analyzed period. Finally, averages and historical coefficients suggest too high returns to conclude for adequacy of Fama and French's model in Brazil.

Bozec, Y. andBozec, R. (2010) analyze the influence of a firm's governance structure, measured by a customized corporate governance score (Report on Business index), on WACC, used as a proxy for firm performance. The study focuses in Canadian companies and finds strong evidence that the cost of capital is decreasing in relation to the quality of corporate governance practices.Using information for Australian firms, Pham et al. (2007) find evidences of a negative relationship between cost of capital and the number of corporate governance practices adopted. Garbrecht (2013) carries out a similar study in Brazil that found no significance for the same relationship.

Nevertheless, it is worth discussing the possible outcomes that the introduction of such practices might bring to companies. This will be done through the analysis of the PE/VC market, which will be introduced in the next section.

\subsection{Private Equity/Venture Capital (PE/VC)}

Private Equity can be characterized as the investment in equity of companies that are not publicly traded and which present specific characteristics in terms of liquidity, information disclosure (asymmetry) and return (RAMALHO et al., 2011). Usually such investments present a higher level of risk and could be classified as investment in alternative assets. The higher levels of return targeted by $\mathrm{PE} / \mathrm{VC}$ industry are based on experience acquired through previous investments, introduction of a governance structure that reduces information asymmetry and the implementation of objective plans that add equity value. 
Although the term has been more widely known for the successful experiences that "began in garages" of the Silicon Valley (USA), according to Sahlman (1990), venture capital can be described as a

"professionally managed pool of capital that is invested in equity-linked securities of private ventures at various stages in their development. [...] The prevailing organization form in the industry is the limited partnership, with the venture capitalists acting as general partners and the outside investors as limited partners" (SAHLMAN, 1990, p. 473)

The term Venture Capital alone is more commonly used to address commitment of a relatively small portion of private capital to early stage ventures or projects, like those that characterized many of the successful icons of technology. Such investments are usually directed to a small amount of assets and are riskier than the ones made on companies at a later stage of development. Despite the fact that Venture Capital is often referred to as a type of PE (RAMALHO et al., 2011), this study refers to Private Equity and Venture Capital as one single term, PE/VC. In general, organizations in this industry manage financial resources from one or more investors with a long-term perspective (RIBEIRO, 2005). Overall, funding occurs through emission of shares (with or without voting rights), participation quotes, convertible debentures, options, subscription bonuses or warrants. After a few years, shareholding is liquidated and all invested funds, as well as proceeds, are returned to investors.

Comodo (2009) and Ramalho et al. (2011) suggest that part of the interest in $\mathrm{PE} / \mathrm{VC}$ investment in Brazil is due to institutional improvement of emerging economies, a situation with high level of risk but also higher returns when compared to mature economies (MINARDI et al., 2013). As part of the financial system in Brazil, $\mathrm{PE} / \mathrm{VC}$ represents a solid option for financing, participating in $45 \%$ of all the IPO's between 2004 and 2013 (BASTOS; 2014)While investigating the differences between PE/VC models in Brazil and US, Comodo (2009) suggests that the American model relies more heavily on leverage, but that success will depend more broadly on strategy and adjustment to local characteristics (RIBEIRO, 2005; COMODO, 2009).Contrasting case studies and theory, Comodo (2009) suggests the Brazilian model is more characterized by 
interventionism, with more hours of direct contact and dedication to invested companies, and better returns. Data from Ramalho et al. (2011) indicatesthe industry is predominantly constituted by independent organizations and organizations connected to financial institutions. Minor groups include corporate ventures and financial institutions under government control such as BNDESParPrivate Equity and BNDESPar Venture Capital. The amount of committed capital by this later group suggests Brazilian government is responsible for only a little share (less than $3 \%$ ) of total committed capital in the country (RAMALHO et al., 2011).That contrasts with the number of companies under BNDESPar Private Equity's and BNDESPar Venture Capital's management, which represent nearly $10 \%$ of total. This reinforces the government's role as a promoter of growth among small and medium sized companies as well as an investor of independent funds. Table 1 summarizes the evolution of PE/VC composition from 2004, 2008 and 2009, according to Ribeiro (2005) and Ramalho et al. (2011).

Table 1 - Fund Manager Affiliations

\begin{tabular}{|c|c|c|c|c|c|c|}
\hline \multirow[b]{2}{*}{ Affiliation } & \multicolumn{3}{|c|}{ Number of fund managers } & \multicolumn{3}{|c|}{ Commitments (US\$ Billion) } \\
\hline & 2004 & 2008 & 2009 & 2004 & 2008 & 2009 \\
\hline Independent Fund Managers & 45 & 107 & 116 & 3,0 & 20,5 & 29,0 \\
\hline Private & 45 & 100 & 109 & 3,0 & & 26,0 \\
\hline Public & & 7 & 7 & & & 3,0 \\
\hline Financial Institutions & 20 & 15 & 16 & 2,1 & 5,3 & 5,8 \\
\hline Corporate Ventures & 4 & 3 & 2 & 0,3 & 0,5 & 0,4 \\
\hline Public Sector & 2 & 2 & 2 & 0,2 & 0,4 & 1,0 \\
\hline Angels & & & 5 & & & \\
\hline Total & 71 & 127 & 141 & 5,6 & 26,7 & 36,2 \\
\hline
\end{tabular}

Committed capital in 2009 was predominantly concentrated on Private Independent fund managers (72\%) and on funds affiliated with financial institutions (16\%), both of which presented the highest growth rate in committed capital and number of participants during the analyzed period (RAMALHO et al., 2011).

Initially, the Holding structure was more popular among PE/VC organizations, given the Brazilian legal and tax system. That model evolved to the Limited Partnership that resembled the US model but adjusted to local regulation. The governance model ruled by CVM has become increasingly popular over the last years, with a number of adjustments that stem from legal responsibility of the 
limited partners until tax levied on income from investment operations. Companies have been able to comply with the differentiated levels of corporate governance, benefiting from higher standards of governance practices, higher market valuation and higher participation of foreign investors. Such governance model is also prone to special chambers of negotiation that benefit from faster decisions, when compared to regular jurisdictional processes (RIBEIRO, 2005; RAMALHO et al., 2011). Despite the legal structure advancements and the growth of private groups' participation, a number of publicly traded Brazilian companies are controlled by family groups, whose decisions very frequently prevail due to their absolute majority of voting rights (RAMALHO et al., 2011).

Many PE/VC studies have focused on the performance improvements of invested companies (UCHIMURA, 2011; TESTA; LIMA, 2013; MINARDI et al, 2013; BASTOS, 2014). Eller (2012) investigates evidence of higher long term (three years) performance of PE/VC backed IPOs in Brazil. Funds also work as efficient promoters of governance mechanisms within the invested organization. More active roles are assumed, including pre-investment contracts, board seats, detailed shareholder agreements, management influence and veto clauses regarding capital structure. PE/VC participation also enables better network, including better terms of negotiation with banks and auditors. Eller (2012) analyzes126 IPOs between 2004 and 2011 finding no influence of PE/VC on performance of the first month. However, this influence becomes highly significant after $6^{\text {th }}$ month and maintains until $24^{\text {th }}$ month, suggesting that influence of $\mathrm{PE} / \mathrm{VC}$ is more relevant during first months and returns tend to market average after a while. Following that study, Bastos (2014) uses information on Brazilian companies from different economic sectors that went public between 2004 and 2013 to analyze the impact of PE/VC funds on long term stock performance. Regression analysis covered periods of one month to three years after IPO. Results demonstrated abnormal returns and cumulative abnormal returns positively affected by the presence of $\mathrm{PE} / \mathrm{VC}$ funds only for the period of six months after IPO.

In order to investigate the influence of $\mathrm{PE} / \mathrm{VC}$ funding on underpricing in the Brazilian market, Bottai (2013) groups IPO data from 2004 to 2013 into PE/VC funded IPO's and non-PE/VC funded IPOs, as well as IPOs priced below, on or 
above the preliminary prospectus price range. IPOs were also grouped into different sectors and grouped by IPO coordinator. The author tested the hypothesis that presence of $\mathrm{PE} / \mathrm{VC}$ funds among investors reduces information asymmetry and reduces underpricing. In order to maintain their credibility, PE/VC funds tend to present good investment opportunities to the market. Thus, price adjustments and underpricing should be smaller, given the good relationship between PE/VC funds and IPO coordinators, both interested in raising the highest amount of capital possible. The study used a number of control variables, including proxies for the level of information held by investors and for adjustment of demand. Results indicate that PE/VC backed IPOs presented higher demand when compared to non-PE/VC backed IPOs, but no significance for the relationship between $\mathrm{PE} / \mathrm{VC}$ and underpricing.

Hellmann andPuri (2002 - 2) estimate the importance of the PE/VC industry on selecting and monitoring good firms as well as accelerating innovation. Their importance is well recognized by innovating firms, which carefully select their investor based on the value they add to the company (HELLMANN; PURI, 2002). It is also acknowledged that these funds add human capital and expertise in the form of participation on board decisions and strategic management of the invested businesses. It is interesting to note that $\mathrm{PE} / \mathrm{VC}$ backed companies will accelerate both successes and mistakes. Analyzing information gathered from 1994 to 1997 on 173 start-up companies, Hellman andPuri (2000) find that innovators are more likely and faster to receive $\mathrm{PE} / \mathrm{VC}$ financing. Additionally, once $\mathrm{PE} / \mathrm{VC}$ comes into play, the likelihood of the first product sale increases by 1,88 times overall.

For instance, Gorman and Sahlman(1987) survey 49 well established US PE/VC firms to obtain more detail on their role towards invested companies. Their study indicates firms' partners play a significant direct monitoring role, especially in moments of crisis or throughout specific projects, but mostly professionalizing management, helping with external relationships, mentoring and hiring executives, among other contributions. Contrary to the hypothesis that venture capitalists delegate monitoring to junior associates and spend little time with entrepreneur, few partners do so. In fact a median respondent spends $60 \%$ of their time with the invested company. Survey resultsalso indicate that firms tend to 
specialize in a specific stage of development (SAHLMAN, 1987; TESTA; LIMA, 2013).With regards to the routine of PE/VC firms, the involvement with invested companies is not restricted to funding. Other tasks are also undertaken that will influence the operational and economic results (TESTA; LIMA, 2013). Other factors will influence the stage and amount of time invested. When the PE/VC fund is the lead investor, it will invest more time than in other stages and roles. To the venture capitalist, the entrepreneur is the company andinvolvement of the partners tends to be more crisis or project oriented, as a monitoring function. This relationship significantly reduces the conflicting directions of entrepreneurs and capitalists: while the first will want to keep the business alive, the later will want to keep it profitable (SAHLMAN, 1987).

With regards to selecting firms according to their development stage, Sahlman (1990) mentions different stages that can be susceptible to investment. The first one, Seed Investment, can be characterized by the completion of a product or service design, with no production for sale. A Start Up stage can be characterized by the formation of a complete management team, with less than a year of operation and usually dedicated to performing initial tests in the market. The Early Development stage is characterized by the establishment of a modest manufacturing and commercializing process, with no focus in profit maximization. The Expansion Stage that follows results from real qualitative feedback from the market, enabling the estimation of future market penetration as well as the needs for equipment, inventory and working capital. The following two stages can be characterized by poor financial results but significant economic results, requiring further expansion and product development. Since risk has already been greatly reduced, additional funding can be provided by banks if there are already enough assets to secure the transaction. This funding option also contributes to limit equity dilution. During the Bridge Stage, or Mezzanine Investment stage, a more feasible form and time of exit may be in discussion and depends a great deal on the conditions of the stock market and of the economic situation. In this stage it is possible that early stage investorswill cash out and/or other investors will join the venture. The last stage - Liquidity, Cash Out or Exit stage - is one where venture capital firms execute their exit strategy, coping with 
market regulation and sustaining long term value creation. This is where the stock market assumes its additional important role.

Ramalho et al. (2011) argue that the term "buyout" should not be used to describe a company life stage, but rather to describe the means through which this company is acquired at any given point of its life cycle. Prior to Sahlman (1990)'s Early Development stage, they introduce the Startup stage in which no commercialization is yet ongoing. After the Expansion Stage, denominated Later Stage by Ramalho et al. (2011), companies leave the Venture Capital phase into the Private Equity phase, at the Expansion stage, like Sahlman (1990). Ramalho et al. (2011) divide the following phase, Maturity, into Private Equity Later Stage, when activities are much more consolidated, and Distressed stage, when additional investments address possible financial difficulties. Investments stage can be divided into Greenfield, Real Estate, Forestry and Infrastructure and usually take place prior to the Mezzanine stage.

Apart from scale and scope economies, learning-curve effects are responsible not only for the gradual accumulation of the PE/VC operational knowledge, but also knowledge on the specific industry and stage of development. This has a great deal of contribution on the reduction of risk and gains of efficiency an invested company might incur (SAHLMAN, 1990).

From the standpoint of invested companies, the amount received is a long term source of funds with no interest or amortization payment, as well as no collateral, as demanded by traditional sources of capital. From the investor standpoint, however, PE/VC represents a low liquidity, highly risky opportunity that demands a great deal of scrutiny in order to be approved (TESTA; LIMA, 2013). One important feature of $\mathrm{PE} / \mathrm{VC}$ funding agreement is the option to abandon a certain investment that does not perform accordingly with respect to value creation and distribution of investment proceeds. Contract terms will also specify the fund's legal structure, fund's economic life, the form and amount of compensation for general partners, takedown schedules defining how and when limited partners must infuse committed cash, penalties applicable to both general and limited partners, distribution policies, reporting and accounting policies, a number of 
rules to address conflicts of interest and advisory structures that will direct the fund's governance.

Much in the same way that limited partners define an agreement with the general partners, the PE/VC firm will legally structure the relationship with an invested company. The contract has the objective of reducing the agency conflicts and thus addresses key issues in the selection of good investment opportunities. To make sure the entrepreneur routine is highly aligned with the venture capitalists long term objective, agreements are set up in ways that control is guaranteed. First, infusion of capital is staged, so that venture capitalists have the power to take leave at any time they understand the investment cannot perform. Second, a set of appropriate incentives, such as Incentive Stock Option (SILVA, 2014) is defined in order to keep venture managers focused on value creation rather than on salary maximization (SAHLMAN, 1990; SILVA, 2014). Third, the designated general partner becomes actively involved in the management of the invested firm. Finally, venture capitalists define the terms through which both entrepreneurs and themselves can cash in on investments made without jeopardizing the relationship and the long term value of the transaction (SAHLMAN, 1990). Through the Stock-Purchase Agreement, Venture-Capital firms fix the amount that will be invested and the timing such cash infusions will take place. It can also define the form of investment, the most common of which being purchases of convertible preferred stock, defining the purchase price, liquidation/exit terms, other dividend and payment terms. These agreements also define the standard and frequency of information disclosure between invested companies and their respective funds, as well as the terms with which a governance board will be formed. All such terms carry the objective of reducing the alignment gap that exists between the parties involved and reducing the inherent risk, while simultaneously increasing the professionalization of the management team of invested companies and, above all, enhancing the likelihood of long term value creation for the portfolio (SAHLMAN, 1990).

Pham et al. (2007) draw attention on the fact that firms with high levels of leverage may be partially unaffected by benefits from corporate governance on 
cost of equity, individually. The study adds significant input on the importance of additional players, such as PE/VC funds, on the board.

Bravand Gompers (1997)identify improvements on the reputation of invested companies' as well as improved communication channels with financial institutions and primary investors. In their study in US, small non-venture backed companies (both IPO and non-issuing) presented lower performance than PE/VCbacked firms. One of the reasons is information asymmetry and its associated costs imposed by small non-PE/VC backed firms. Siqueira et al. (2011) add to the conclusion that $\mathrm{PE} / \mathrm{VC}$ funds will invest in their reputation. For instance, their study in Brazil found that likelihood for success increases with the size of the fund and with the number of investments, the latter being at a decreasing marginal rate.

Many studies (GIOIELLI, 2008; GARBRECHT, 2013; GIOIELLI, 2013; MINARDI et al., 2013; TESTA; LIMA, 2013) state that PE/VC participation reinforces the importance ofwell-established corporate governance mechanisms. According to Gioielli (2013), given the concern of funds with their own reputation and credibility, it is expected that invested companies will be reliable in terms of growth opportunities and information disclosure, reducing opportunistic behavior. Thus, it is expected that $\mathrm{PE} / \mathrm{VC}$ influences the corporate governance structure of invested companies (PHAM et al., 2007; BOZEC, Y.; BOZEC, R, 2010; SILVA, 2014). Role of funds is crucial for companies that face limited access to the credit market (RIBEIRO, 2005), companies with a high percentage of intangible assets and/or companies under financial stress. The entrance of such organizations on the capital structures of invested companies will occur if a significant upside potential exists and is worth the governance efforts. Using information of 92IPOs from 2004 to 2010 in Brazil, she demonstrates that the presence of funds reduces earnings management and increases independence of the board, a situation that, among other upsides, benefits minor shareholders.Minardi et al. (2013) support that view for the Brazilian market stating that funds' performance throughout time must be consistent, since their records provide good reference with regards to future opportunities. It's on the best interest of these funds to attain good results in order to obtain new funds. Thus, credibility is key and having a qualified team to select and manage good investment opportunities is essential to achieving a 
performance that outweighs that of the market. Silva (2014) also reinforces the role of funds as disseminators of good practices of Corporate Governance, stating that invested companies tend to more intensely implement those practices when compared to non-invested companies. Implementation of Corporate Governance practices include monitoring as well as taking part on strategic definitions regarding incentives and transparency.

According to Gioielli et al. (2013), invested companies and non-invested companies presented statistically similar characteristics regarding equity value at the moment of the IPO (net revenue, net income, funding obtained through IPO, market value at IPO, book-to-market ratio, total assets, sales growth rate, leverage and ROA). On the other hand these two groups differ in that invested companies are more concerned with auditing certification both during IPOs and SEOs. Lastly, the likelihood of undergoing a new public equity offer during the 5 quarters right after the IPO is higher (13,2\% against 2,8\%) for invested companies.

All in all, $\mathrm{PE} / \mathrm{VC}$ total expenditure is still significantly smaller than total corporate investment carried out in a year (SAHLMAN, 1990). Nevertheless results from $\mathrm{PE} / \mathrm{VC}$ investment have enabled creation of important entrepreneurial worldwide icons, such as Intel Semiconductors, Google, Apple Computer, eBay, Amazon, Cisco Systems, Microsoft, Mosaic (Netscape), Sun Microsystems, Genentech, Starbucks and many other examples in areas such as nanotechnology, biotechnology and health sector (GOMPERS; LERNER, 2001; RAMALHO et al., 2011). PE/VC payoff for these companies also exceeded the most optimistic estimates. That however does not mean that this funding model does not have its counterexamples: the existence of the option to abandon per se points out that some failure experience has been gained throughout the industry's lifetime, with millionaire bets being liquidated. Even successful IPO's can prove unprofitable in subsequent operating periods. Thus, even though risk is gradually reduced throughout the development stages, it is not eliminated just because of the participation of a PE/VC firm (SAHLMAN, 1990). 


\subsection{Cost of Capital and the PE/VC industry}

With Brazil's recent development of the stock market, other sources of funding, with different legal arrangements and different cost structures, have become increasingly important. $\mathrm{PE} / \mathrm{VC}$ funding is one of these and, although transactions per se do not take place in the market, it constitutes one of the most important exit means for investors, conditioning the success and profitability of such transactions.

Gompers et al. (2014) explore PE/VCinvestors practices regarding Financial Engineering, Governance Engineering and Operational engineering. In order to verify adherence to existing PE/VC investment theory, 79 buyout investors were submitted to a 92 questions survey. Results point out that the preferred investment life time is five years (GORMAN; SAHLMAN, 1987; GOMPERS et al., 2014) and evaluations of invested managers forecasts is subject to a $20 \%$ discount (for optimism), on average. Most $\mathrm{PE} / \mathrm{VC}$ funds rely on internal rate of return and multiples of invested capital to evaluate investments. Funds typically target a $22 \%$ internal rate of return. Higher target rates may imply excess return in order to compensate for fees and administrative expenses, other than remuneration. Overall Gompers et al. (2014) reach good conclusions of how PE/VC funds act, what their objectives are and how they structure the business to reach their five year target.

Ribeiro (2005) and Ramalho et al. (2011) state that the rate of return may be influenced by credit market restrictions. However harmful this situation may be, it confers some bargain power to fund managers. They can bid lower prices for good investment opportunities among small companies with good perspective but high credit restriction, generating high return rates. Also, fund managers are better prepared to mitigate eventual risks associated with the venture.

Efficient private fund managers will thrive to find good investment opportunities and at the same time work to increase an invested company's professionalism and profitability. To a great extent, situations like this influence the cost of capital faced by an invested company, since action by an external investor will pursue increasing returns with diminishing debt cost (although that doesn't necessarily 
mean lower debt amount). They also reinforce the importance of studying the relationship between cost of capital and PE/VC. 


\section{Data and Methodology}

This section discusses the methodological procedures adopted to analyze the relationship between WACC and the independent variables including investment by PE/VC funds.

\subsection{Study Sample}

The study focuses on Brazilian companies that went public on BMF\&Bovespa from 2004 to 2013, period of significant increase in the number of enlisted companies and on the amount of resources committed to PE/VC. Apart from the Brazilian economic stabilization, during this period, private companies also dealt with different levels of credit availability, which could contribute for the analysis of the cost of capital in both circumstances.

According to BMF\&Bovespa, there were 262 public offerings, of which 151 IPO's and 111 secondary/follow-ons. The study focused on the IPO activity in the period.

Figure 1 - Initial Public Offers (IPO) per year (2004 - 2013)

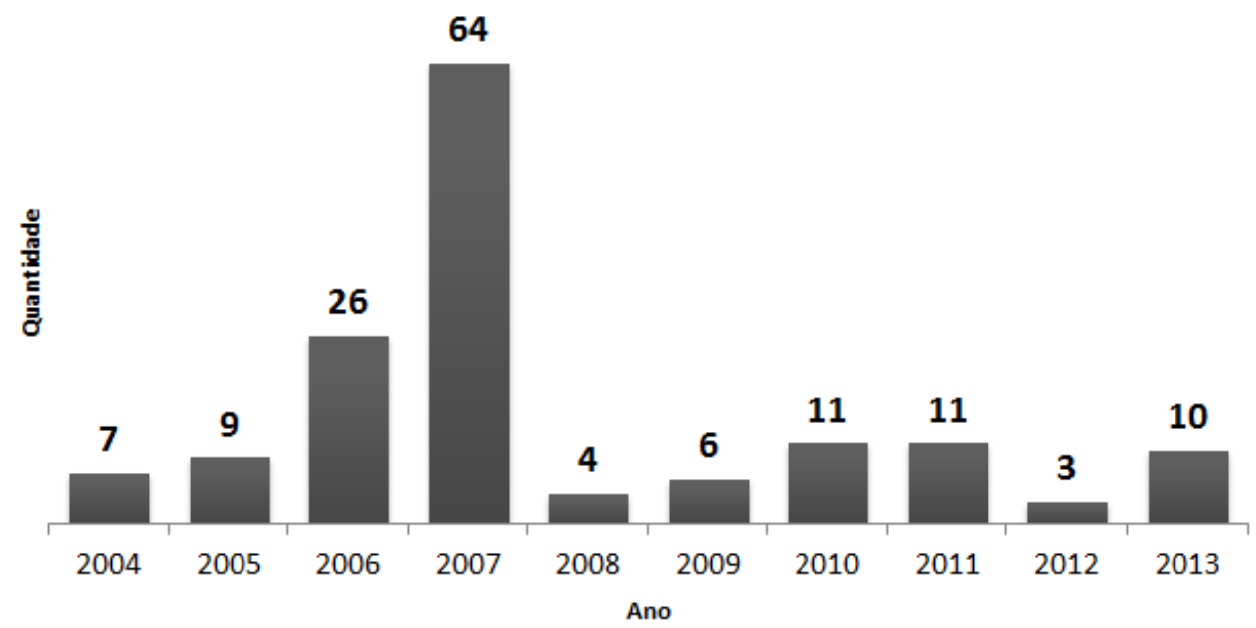


Based on BMF\&Bovespa's information, an attempt was made to obtain all the information from Bloomberg database, specially consolidated Balance Sheets and Income Statement figures. Such and attempt had the intention to allow for replication of this study elsewhere and to enable external contribution. However, the method used to extract the information did not find as complete a database as was possible using Economatica. Information was missing on a few accounts as well as for a few companies that changed their negotiating codes during the period. An individual comparison with Economatica's information proved the latter database more complete, despite the fact that some information was still missing. Thus, Economatica was chosen and each balance sheet and income statement was extracted individually in order to assure information reliability. Additional financial information that was still missing was hand-picked from companies' financial reports available online on their investor relations' web page. For the entire analysis, data was used in yearly figures, mainly to avoid seasonality issues that might otherwise interfere with the results.

Companies were divided into $\mathrm{PE} / \mathrm{VC}$ backed-companies and non-PE/VC backedcompanies.IPO information, including participation of a PE/VC funds, was obtained from the BMF\&Bovespawebsite, as well as from the CVM website, through companies' prospects.

In spite of being more complete and more adjusted to Brazilian economic market, it is worth mentioning that a few inconsistencies were detected in Economatica during the process. A number of reports demonstrated discontinued values for accounts of crucial importance to this study, such as Total Assets, Total Liabilities, Financial Expenses, Debt accounts and other examples. It is possible, for example, to find divergent or incomplete numbers for a company's total debt for the same period in different parts of the consolidated statement. It is also possible to find quarterly blank spots for important accounts such as Total Asset within a single year, suggesting discontinuity of the account. Such inconsistencies were not further investigated and missing information was either obtained or confirmed on each company's investor relation website, whenever possible.

During the analyzed period, 21 companies canceled their registration in the stock market. These companies' information was considered for the period in which 
they were publicly traded. Other companies changed their registration and/or were acquired during the period, changing their trading codes. Such companies include Abnote, Bovespa Holding, Brascan, Company, Inpar S.A., MPX, OHL Brasil, Satipel, Submarino and Visanet, for which information was considered until the effective code change.

The definition of economic sectors for this study was based on but not restricted to that of Economatica and a total of 10 economic sectors ${ }^{1}$ were used according to the companies' business. Economatica groups companies among 18 different economic sectors, but the decision not to use them aimed at both keeping the number of variables concise and respecting each company's economic segment.

Due to differences in the structure and interpretation of their financial statements, banks and financial institutions were not considered in the analysis. Additionally, GP Investments and Tarpon were also excluded from the sample. These companies are, by definition, PE/VC Management Funds, with characteristics that more closely resemble those of financial institutions. Finally, for the companies included in the sample, yearly information that included negative equity and/or negative financial expenses were discarded.

The following table demonstrates the number of companies considered in the final sample, according to their IPO year, after all the filters were applied.

\footnotetext{
${ }^{1}$ Companies were grouped according to the main economic activity into the following denominations: Financial \& Insurance, Construction, Food, Logistics, Industry, Real Estate, Retail, Services, Technology and Utilities.
} 
Table 2 - Number of companies included in the sample

\begin{tabular}{|c|c|c|c|c|c|c|c|c|c|c|c|}
\hline \multirow{2}{*}{$\begin{array}{l}\text { Number of IPO's } \\
\text { Year }\end{array}$} & \multicolumn{11}{|c|}{ Number of companies in each year according to their IPO date } \\
\hline & 2004 & 2005 & 2006 & 2007 & 2008 & 2009 & 2010 & 2011 & 2012 & 2013 & TOTAL \\
\hline Construction & 0 & 0 & 4 & 14 & 0 & 1 & 0 & 0 & 0 & 0 & 19 \\
\hline Financial\&Insurance & 1 & 1 & 3 & 17 & 0 & 3 & 1 & 1 & 1 & 1 & 29 \\
\hline Food & 1 & 0 & 0 & 2 & 0 & 0 & 0 & 0 & 0 & 0 & 3 \\
\hline Industry & 3 & 1 & 4 & 13 & 3 & 1 & 3 & 5 & 0 & 1 & 34 \\
\hline Logistics & 0 & 0 & 1 & 1 & 0 & 0 & 0 & 0 & 0 & 0 & 2 \\
\hline Real Estate & 0 & 0 & 3 & 6 & 0 & 0 & 2 & 1 & 0 & 0 & 12 \\
\hline Retail & 0 & 1 & 2 & 1 & 1 & 0 & 1 & 3 & 1 & 0 & 10 \\
\hline Services & 0 & 0 & 0 & 4 & 0 & 0 & 1 & 1 & 0 & 4 & 10 \\
\hline Technology & 0 & 0 & 5 & 1 & 0 & 1 & 0 & 0 & 0 & 2 & 9 \\
\hline Utilities & 3 & 5 & 4 & 5 & 0 & 0 & 3 & 0 & 1 & 2 & 23 \\
\hline TOTAL & 8 & 8 & 26 & 64 & 4 & 6 & 11 & 11 & 3 & 10 & 151 \\
\hline \multicolumn{12}{|c|}{ Number of companies in each year according to their IPO date, after filters } \\
\hline Year & 2004 & 2005 & 2006 & 2007 & 2008 & 2009 & 2010 & 2011 & 2012 & 2013 & TOTAL \\
\hline Construction & 0 & 0 & 4 & 14 & 0 & 1 & 0 & 0 & 0 & 0 & 19 \\
\hline Financial\&Insurance & 1 & 0 & 1 & 5 & 0 & 2 & 1 & 1 & 0 & 0 & 11 \\
\hline Food & 0 & 1 & 0 & 2 & 0 & 0 & 0 & 0 & 0 & 0 & 3 \\
\hline Industry & 3 & 1 & 4 & 12 & 3 & 1 & 3 & 5 & 0 & 1 & 33 \\
\hline Logistics & 0 & 0 & 1 & 1 & 0 & 0 & 0 & 0 & 0 & 0 & 2 \\
\hline Real Estate & 0 & 0 & 3 & 6 & 0 & 0 & 2 & 1 & 0 & 0 & 12 \\
\hline Retail & 0 & 1 & 2 & 1 & 1 & 0 & 1 & 3 & 1 & 0 & 10 \\
\hline Services & 0 & 0 & 0 & 4 & 0 & 0 & 0 & 1 & 0 & 3 & 8 \\
\hline Technology & 0 & 0 & 5 & 1 & 0 & 1 & 0 & 0 & 0 & 2 & 9 \\
\hline Utilities & 3 & 5 & 3 & 5 & 0 & 0 & 3 & 0 & 1 & 2 & 22 \\
\hline TOTAL & 7 & 8 & 23 & 51 & 4 & 5 & 10 & 11 & 2 & 8 & 129 \\
\hline
\end{tabular}

Source: BMF\&Bovespa and data consolidation by the author.

Table 3 demonstrates the number of observations by industry obtained for each year of the study, after all the filters are applied. In order to be included in the final sample, each WACC observation had to be followed by a valid financial number for each of the explanatory variables that were considered in the model. In total, the final sample contained 612 observations. It is possible to infer that not many companies that went public during the period remained in the stock market long after the IPO. 
Table 3 - Number of observations considered for each year by industry

\begin{tabular}{lcccccccccc}
\hline & \multicolumn{1}{c}{ Number of companies with information in each year } \\
\hline Segment & $\mathbf{2 0 0 4}$ & $\mathbf{2 0 0 5}$ & $\mathbf{2 0 0 6}$ & $\mathbf{2 0 0 7}$ & $\mathbf{2 0 0 8}$ & $\mathbf{2 0 0 9}$ & $\mathbf{2 0 1 0}$ & $\mathbf{2 0 1 1}$ & $\mathbf{2 0 1 2}$ & $\mathbf{2 0 1 3}$ \\
Construction & 0 & 0 & 21 & 72 & 0 & 5 & 0 & 0 & 0 & 0 \\
Financial\&Insurance & 6 & 0 & 4 & 23 & 0 & 10 & 1 & 3 & 0 & 0 \\
Food & 9 & 0 & 0 & 7 & 0 & 0 & 0 & 0 & 0 & 0 \\
Industry & 27 & 3 & 26 & 58 & 12 & 5 & 12 & 12 & 0 & 1 \\
Logistics & 0 & 0 & 6 & 7 & 0 & 0 & 0 & 0 & 0 & 0 \\
Real State & 0 & 0 & 15 & 31 & 0 & 0 & 8 & 2 & 0 & 0 \\
Retail & 0 & 8 & 11 & 7 & 6 & 0 & 1 & 9 & 2 & 0 \\
Services & 0 & 0 & 0 & 15 & 0 & 0 & 0 & 3 & 0 & 4 \\
Technology & 0 & 0 & 32 & 7 & 0 & 1 & 0 & 0 & 0 & 1 \\
Utilities & 23 & 38 & 15 & 28 & 0 & 0 & 12 & 0 & 2 & 1 \\
\hline Total & $\mathbf{6 5}$ & $\mathbf{4 9}$ & $\mathbf{1 3 0}$ & $\mathbf{2 5 5}$ & $\mathbf{1 8}$ & $\mathbf{2 1}$ & $\mathbf{3 4}$ & $\mathbf{2 9}$ & $\mathbf{4}$ & $\mathbf{7}$ \\
\hline & & & & & & & & &
\end{tabular}

Source: Data consolidation by the author.

\subsection{The regression Model}

In this study the structure of analysis integrates the cost of capital analytical framework of Cassotti and Motta (2008), Huang and Ritter (2009) and Albanez (2012), who provide the variables to estimate cost of capital from two different sources (equity and debt). The introduction of a dummy variable to account for $\mathrm{PE} / \mathrm{VC}$ investment will indicate any impact of such participant on the cost of capital.

Like Cassottiand Motta (2008), Huang and Ritter (2009) and Albanez (2012) this study will estimate the cost of equity and the cost of debt to calculate the WACC, the dependent variable, as below:

$$
W A C C_{i}=\frac{D}{D+E}\left(1-T_{c}\right) K_{D, i}+\frac{E}{D+E} K_{E, i}
$$

where $W A C C_{i}$ is the Weighted Average Cost of Capital for firm $i$. D and E denote, respectively, the book value of debt (short-term and long-term debt) and equity (common and preferred stock). As in Bozec, Y. and Bozec, R. (2010), debt and preferred stock book values are used as proxies for market value. $T_{c}$ is the marginal corporate tax rate. $\mathrm{K}_{\mathrm{D}}$ and $\mathrm{K}_{\mathrm{E}}$ are the cost of debt (pre-tax) and equity. 
Cost of equity estimates are based on CAPM model, adjusted for the Brazilian market, as in Cassotti and Motta (2008).

$$
K_{E, i}=R f+\beta[E(R m)-R f]+C R
$$

where $K_{E}$ stands for the cost of equity for firm $i, R f$ is the risk free rate and $\beta_{\mathrm{i}}$ is market beta for firm i.E(Rm) is the expected return on the market portfolio, $[\mathrm{E}(R m)-R f]$ is the market risk premium and $C R$ is the country risk. As stated by Oliveira and Martelanc (2013) and Argolo et al. (2012), no other model for calculating the cost of capital has yet achieved as widespread use as CAPM. Thus, its use encounters significant unanimity, including in Brazil, where usage rates are also high (GARRÁN, 2006; apud OLIVEIRA; MARTELANC, 2013).

The CAPM model was used to calculate the cost of equity $\left(K_{E, i}\right)$, using the US TBond with 10 years maturity as the risk free rate. The S\&P500 was used as the market return. In order to estimate the market premium rate, a 10 year average of the difference between the market return and the risk free rate was used.

As for the beta estimates it is worth mentioning that an attempt was made to use estimates from comparable companies in the north-American market, for which the usual source is Damodaran's database. However, a recent change imposed by Damodaran's source of information restricted its disclosure and use for any purpose, including academic studies, causing the online removal of present and past beta estimates. Thus, all beta estimates of were calculated using Economatica stock price information converted to US dollars, compared to the market return, represented by the S\&P500.

Finally, also as in Cassotti and Motta (2008) and Albanez (2012), a measure of risk representing the Brazilian scenario was added to the capital return estimate. Such measure, represented by the EMBI+ index, was obtained online from Portal Brasil (www.portalbrasil.net). 
For the cost of debt, $K_{D, i}$, quarterly Short term and Long term debt information was obtained from balance sheet numbers and quarterly financial expenses were extracted from income statements, all available on Economatica's database. In order to avoid any exchange rate disturbance in the calculation, quarterly information for both Short Term/Long Term Debt and Financial Expenses was converted to US dollars using quarterly exchange rates. This information in turn was used in the following expression:

$$
K_{D, i}=\frac{\sum_{i} \text { Financial Expenses }}{\text { Short Term }+ \text { Long Term Debt }}
$$

Where $\sum_{i}$ Financial Expensesis the sum of Financial expenses in a given fiscal year and Short Term + Long Term Debt is the quarterly average of short term and long term debt a company registered in the balance sheet in a given fiscal year.

In summary, in order to estimate the WACC denominated in US dollars, the information was obtained as follows:

- $\quad$ Cost of equity $\left(\mathrm{CAPM}-K_{E}\right)=$

o $R f=$ Yearly US T-Bond with 10 years maturity;

o Beta estimates: Economaticadaily stock price information converted to US dollars using the daily exchange rate, compared to daily market return, represented by the S\&P500 daily quotes;

o $E(R m): \mathrm{S} \& \mathrm{P} 500$ yearly return;

o $[\mathrm{E}(R m)-R f]: 15$ year average of difference between yearly data for S\&P 500 and US T-Bond with 10 years maturity;

o $C R$ : Country risk represented by EMBI+ index for Brazil.

- Cost of Debt $\left(K_{D}\right)=$ average of quarterly Financial Expenses divided by Short Term/Long Term Debt, all converted to US dollars using quarterly exchange rates. 
An additional analysis used data in Brazilian Real currency, for the estimation of WACC. For this regression information was obtained as follows:

- Cost of equity $\left(\mathrm{CAPM}-K_{E}\right)=$

o $R f=$ Interbank depositary certificate $(\mathrm{CDI})$ yearly quotes;

o Beta estimates: Economaticadaily stock price information, compared to the market return, represented by daily Ibovespa quotes;

o $E(R m)$ : Ibovespa yearly return;

o $[\mathrm{E}(R m)-R f]: 10$ year average of difference between yearly Ibovespa and CDI;

- Cost of Debt $\left(K_{D}\right)=$ average of quarterly financial Expenses divided by Short Term/Long Term Debt in Brazilian Real.

As as in Bozec, Y. and Bozec, R. (2010), book values are used as proxies for market value in order to obtain debt and equity respective weights.

In order to analyze the cost of capital, four groups of variables, both quantitative and qualitative, were introduced in the analysis structure. As part of the quantitative variables, a group of financial variables included parameters for fixed asset, cash flow, EBITDA, net income, book value and size. Among the qualitative variables, three groups of variables were introduced, the first of which indicating whether or not companies had an ADR and were part of the new market (Bovespa's differentiated levels of corporate governance). The second group of qualitative variables is a set of dummies introduced to indicate to which economic segment companies belong to. Third and final group of qualitative variables included two dummies indicating whether or not companies financial information referred to the biennium 2006/2007, years of great increase in the number of IPO's, or to 2008, a crucial year for the financial crisis. In the end, a total of 18 independent variables were considered for the construction of the model.

The consideration of each variable followed a research on variables used in revised literature (SILVA; LEAL, 2006; CASSOTTI; MOTTA, 2008; GIOIELLI, 2008; HUANG; RITTER, 2009; ALBANEZ, 2012; MINARDI et al., 2012; TESTA; LIMA, 2013;) and discussions on the possible influence each parameter 
might have on cost of capital. From the financial group, high levels of IMMOBILIZATION, for example, may represent low liquidity, increasing the risk and thus the cost of capital. In order to evaluate the influence of capital immobilization over its cost two alternative variables were considered.

$$
\begin{aligned}
& \text { NetFxAsset_TotAsset }=\frac{\text { Net Fixed } \text { Aset }}{\text { Total Asset }} \\
& \text { NetFxAsset_Equity }=\frac{\text { Net Fixed Aset }}{\text { Equity }}
\end{aligned}
$$

In order to estimate the amount of available cash and how much of it is committed to present and future activities, two variables were evaluated. A satisfactory amount of AVAILABLE CASH for different purposes, including investments, could contribute to reduce the cost of capital of that company. In that sense, both the Operating Cash Flow (OCF) and the ratio between the Free Operating Cash Flow and CAPEX were analyzed.

$$
\begin{aligned}
& \text { ocf_ln = Logarithm of Operating Cash Flow } \\
& \text { ofcf_capex }=\frac{\text { Operating Free Cash Flow }}{\text { CAPEX }}
\end{aligned}
$$

One variable was included to evaluate a company's CAPACITY TO GENERATE CASH and fulfill external commitments. EBITDA_FinExp measures the ration between EBITDA and Financial Expenses. The amount by which this relationship is greater than unity can not only represent a measure of return, but also the capacity to pay third parties' debt, reducing the cost of capital. 


$$
\text { ebitda_finexp }=\frac{E B I T D A}{\text { Financial Expenses }}
$$

in which the Financial Expenses represent a sum of quarterly information converted to the respective quarterly US dollar exchange rate.

Another variable was considered to account for the influence of the company's return on the cost of capital.

$$
\text { netincome_roa }=\frac{\text { Net Income }}{\text { Total Asset }}
$$

It is expected that higher net income earned over the total asset will increase the return and reduce the overall cost of capital.

The overall market perception of the COMPANY'S GROWTH CAPACITY and its influence on the cost of capital was estimated through two variables. One of them, size_mv_ln, measures the logarithm of total market capitalization. The other variable, book_to_mkt, accounts for the relationship between a company's book value and its market value.

$$
\text { size } \_ \text {mv_ln }=\text { Stock Price } \mathrm{x} \text { Number of Outstanding shares }
$$

$$
\text { book_to_mkt }=\frac{\text { BookValue of Equity }}{\text { size_mv }}
$$

It is expected that the better the evaluation attributed by the market, the lower will be the cost of capital, since perceived risk will be lower. 
Apart from the market value of equity, other two different measures for COMPANY'S SIZE were considered. It is expected that bigger companies will represent lower risks, thus reducing the cost of capital. Measuring the logarithm of total book value of asset or the logarithm of total net revenue earned in a fiscal year may contribute to estimate a company's overall capacity and risk.

size_asset_ln $=$ logarithm of book value of total asset

size_rev_ln $=$ logarithm of net revenue obtained from income statement

Apart from the financial variables, three different groups of control variables were used. A group of influential variables introduced in the model refers to the companies' insertion in the stock market. In this group, a set of dummy variables were used to control for:

- ADR: a dummy variable that assumes the value of 1 whether a company has an American Depositary Receipt or 0 otherwise. The existence of an ADR may represent better reputation not only in the domestic market but also in the foreign market, which improves the overall funding conditions, thus reducing its cost;

- NM: a dummy variable that assumes the value of 1 if the company is part of Bovespa's New Market, according to Bovespa's Differentiated levels of Corporate Governance, or 0 otherwise. It is expected that greater levels of Corporate Governance represent better management structures, lower risk and thus lower costs.

A third group of variables controls for the industry to which the company belongs predominantly. 10 dummy variables were used to account for each of the 10 
industries included ${ }^{2}$ in the model. Each industry's dummy assumes the value of 1 whenever a company belongs to that industry and the value of 0 otherwise. Once the sample was defined and considering a few companies closed their registration in the stock Market, not every company had the financial information available for every year of the studied period. In that sense, most of the information used in the econometric tests is concentrated on the first four years of the period.

A fourth group of variables controls for specific periods during which macroeconomic circumstances played significantly higher influence. Two dummy variables were used:

- IPO_boom: a dummy variable that assumes the value of 1 if the information refers to years 2006 or 2007, years of great increase in the number of IPOs in Brazil, or 0 otherwise. This variable is expected to reduce the cost of capital, since the macroeconomic circumstances of the above mentioned years were more favorable;

- Crisis: a dummy variable that assumes the value of 1 if the information refers to the year 2008, year of the most recent financial crisis, or 0 otherwise, Contrary to 2006 and 2007, 2008 is considered the year when the recent financial crisis produced the most negative consequences. Thus it should be expected to increase the cost of capital;

Finally, a dummy variable was introduced in the model to account for investment by PE/VC funds, PE. This variable is analyzed solely at the IPO date, assuming the value of 1 in cases where the company had a PE/VC fund among its shareholders or the value of 0 otherwise. A priori it is expected that this variable will represent a reducing effect on the overall cost of debt, but it is worth considering the possibility that the presence of PE/VC funds may increase the return on invested capital. In that case, CAPM measured returns should be higher and, depending on the company's capital structure, the overall cost of capital could be higher. Thus, it is not possible to define upfront which will be the influence of PE/VC on WACC. Further analysis of this variable will be discussed in the results analysis section.

\footnotetext{
${ }^{2}$ Companies were grouped according to the main economic activity into the following denominations: Financial \& Insurance, Construction, Food, Logistics, Industry, Real Estate, Retail, Services, Technology and Utilities.
} 
Table 4 consolidates the variables that were analyzed and included in the model and whether a negative or positive effect should be expected on the dependent variable, WACC. A negative expected effect indicates that such variable will reduce the cost of capital, while a positive expected effect will increase it. For some variables the impact is not straight forward at first, in which case a Positive/Negative register indicates no certain effect is expected. 


\section{Table 4 - Independent variables description with expected signs}

This table summarizes the independent variables and the empirical predictions tested in this paper with regard to the WACC: 1) Net Fixed Asset ratio: ratio between total fixed asset and total asset; 2) Net Fixed Asset ratio 2: ratio between total fixed asset and equity; 3) Operating Free Cash Flow: logarithm of operating cash flow; 4) Operating Free Cash Flow over CAPEX: ratio between operating cash flow and amount dedicated to CAPEX; 5) EBITDA over Financial Expenses: total EBITDA of the exercise divided by the amount of financial expenses; 6) ROA: Net income divided by total asset; 7) Book to Market: book value of equity divided by market value of equity; 8) Market Capitalization: logarithm of total volume of outstanding shares multiplied by the stock price of each period; 9) Size of Asset: logarithm of total asset; 10) Size of Revenue: logarithm of total net revenue; 11) Private Equity: dummy that assumes the value of one if PE/VC among shareholders and 0 otherwise; 12) ADR: dummy that assumes the value of 1 if company has ADR or 0 otherwise; 13) New Market: dummy that assumes the value of 1 if company is part of BM\&FBovespa's 'Novo Mercado' or 0 otherwise; 14 to 23) Industries: dummy introduced for each type of industry that company belongs to, assuming the value of 1 if the company belongs to a specific industry or 0 otherwise; 24) IPO Boom years: dummy that assumes the value of 1 if financial information refers to 2006 or 2007 and 0 otherwise; 25) Crisis year: dummy that assumes the value of 1 if financial information refers to 2008 or the value of 0 otherwise. Source: author'sanalysis.

\begin{tabular}{|c|c|c|c|}
\hline Variable & Model Variable & Formula & Expected Sign \\
\hline \multicolumn{4}{|l|}{ Dependent Variable } \\
\hline WACC & WACC2 & $W A C C_{i}=\frac{D}{D+\varepsilon}\left(1-T_{e}\right) K_{D,}+\frac{\varepsilon}{D+\varepsilon} K_{E L}$ & \\
\hline \multicolumn{4}{|l|}{ Independent Variables } \\
\hline \multicolumn{4}{|l|}{ Financial } \\
\hline Net Fixed Asset ratio & netfxasset_totasset & Net Fixed Asset / Total Asset & Positive \\
\hline Net Fixed Asset ratio 2 & netfxasset_equity & Net Fixed Asset / Equity & Positive \\
\hline Operating Cash Flow & $o c f_{-} l n$ & $\log$ (operating cash flow) & Negative \\
\hline $\begin{array}{l}\text { Operating Free Cash Flow } \\
\text { over Capex }\end{array}$ & ofcf_capex & $\begin{array}{l}\text { Operating Free Cash Flow / } \\
\text { CAPEX }\end{array}$ & Negative \\
\hline $\begin{array}{l}\text { EBITDA over Financial } \\
\text { Expenses }\end{array}$ & ebitda finexp & EBITDA / Financial Expenses & Negative \\
\hline ROA & netincome_roa & Net Income / Total Asset & Negative \\
\hline Book to Market & book_to_mkt & $\begin{array}{l}\text { Stock Price } x \text { Number of Outstanding } \\
\text { Shares / Book value of equity }\end{array}$ & Negative \\
\hline Market Capitalization & size_mv_ln & $\begin{array}{l}\text { Logarithm of Stcck Price x Number of } \\
\text { Outstanding Shares }\end{array}$ & Negative \\
\hline Size of Asset & size_asset_ln & Logarithm of Total Asset & Negative \\
\hline Size of Revenue & size_rev_ln & Logarithm of Net Revenue & Negative \\
\hline \multicolumn{4}{|l|}{ Focus variable } \\
\hline Private Equity & pe & $\begin{array}{l}\text { Dummy for the existence of a } \\
\text { Private Equity fund in IPO }\end{array}$ & Negative/Positive \\
\hline \multicolumn{4}{|c|}{ Market registration variables } \\
\hline ADR & $a d r$ & $\begin{array}{l}\text { Dummy for the existence of an } \\
\text { American Depositary Receipt }\end{array}$ & Negative \\
\hline New Market & $n m$ & $\begin{array}{l}\text { Dummy for New Market (Bovespa's } \\
\text { Corporate Governance levels) }\end{array}$ & Negative \\
\hline \multicolumn{4}{|l|}{ Segment } \\
\hline Industry & industry & Dummy for industry & Negative/Positive \\
\hline Utilities & utilities & Dummy for utilities & Negative/Positive \\
\hline Financial\&Insurance & financial_insurance & Dummy for financial \& insurance & Negative/Positive \\
\hline Food & food & Dummy for Food & Negative/Positive \\
\hline Retail & retail & Dummy for Retail & Negative/Positive \\
\hline Construction & construction & Dummy for Construction & Negative/Positive \\
\hline Technology & technology & Dummy for Technology & Negative/Positive \\
\hline Real Estate & real_estate & Dummy for Real Estate & Negative/Positive \\
\hline Logistics & logistics & Dummy for Logistics & Negative/Positive \\
\hline Services & services & Dummy for Services & Negative/Positive \\
\hline \multicolumn{4}{|c|}{ Macroeconomic Circumstances } \\
\hline IPO Boom years & ipo_boom & Dummy for 2006 and 2007 & Negative \\
\hline Crisis Year & crisis & Dummy for 2008 & Positive \\
\hline Years Since IPO & year_from_ipo & Number of years since IPO & Negative/Positive \\
\hline
\end{tabular}


As reported on table 5, maximum and minimum values for some variables differ from the rest of their sample. The maximum value of book_to_mkt, for example, represents MPX's 2008 value, a time when the company lost nearly $87 \%$ of its value. With regards to ebitda_finexp, $\mathrm{BHG}$ and Smiles respond for, respectively, the minimum and maximum values, generated by the EBITDA of their first years of public trading. Finally, Inpar S/A (currently ViverIncorporadora S/A), accounts for the maximum ofcf_capex of 1.701,90, which is a combination of a reverted trend in the value of operational free cash flow and significant fall in the capex yearly value. Similar situation generated OGX's ofcf_capex value of $-1.673,78$. To some extent, the quality of the analysis could be improved by removing outliers, a procedure that could ultimately compromise the results (Gujarati, 2000). Distorting values such as these were removed from the sample in order to avoid any disruption of the estimated model due to outliers. Company yearly estimates were also discarded whenever any of the variables considered presented a missing value, thus allowing for the use of 612 observations in the final sample used for the regression analysis. 


\section{Table 5 - Descriptive Statistics}

This table summarizes the mean, median, maximum, minimum, standard deviation, skewness and kurtosis of the dependent variable (WACC) and the independent variables. Statistics reflect yearly information for 129 companies from 2004 to 2013. Data source: Economatica and comapanies' web page.

\begin{tabular}{|c|c|c|c|c|c|c|c|c|c|}
\hline Variable & Mean & Median & Maximum & Minimum & Std. Dev. & Skewness & Kurtosis & Observations & Frequency \\
\hline WACC2 & 0,12 & 0,10 & 0,40 & 0,03 & 0,06 & 1,65 & 6,49 & 612 & Yearly \\
\hline BOOK_TO_MKT & 1,50 & 0,67 & 193,42 & 0,02 & 8,43 & 20,21 & 446,80 & 612 & Yearly \\
\hline EBITDA_FINEXP & 5,71 & 2,60 & $1.166,72$ & $-812,22$ & 59,28 & 8,00 & 300,86 & 612 & Yearly \\
\hline NETFXASSET_EQUITY & 0,61 & 0,34 & 5,30 & 0,00 & 0,75 & 2,01 & 8,24 & 612 & Yearly \\
\hline NETINCOME_ROA & 0,04 & 0,04 & 0,56 & $-1,24$ & 0,10 & $-3,35$ & 56,11 & 612 & Yearly \\
\hline OFCF_CAPEX & 5,49 & 0,93 & $1.701,90$ & $-470,36$ & 101,09 & 14,30 & 238,49 & 612 & Yearly \\
\hline SIZE_MV_LN & 13,60 & 13,64 & 17,90 & 8,37 & 1,43 & $-0,31$ & 3,54 & 612 & Yearly \\
\hline SIZE_REV_LN & 13,12 & 13,15 & 17,50 & 4,95 & 1,45 & $-0,85$ & 5,79 & 612 & Yearly \\
\hline PE & 0,44 & 0,00 & 1,00 & 0,00 & 0,50 & 0,22 & 1,05 & 612 & Yearly \\
\hline ADR & 0,06 & 0,00 & 1,00 & 0,00 & 0,24 & 3,63 & 14,17 & 612 & Yearly \\
\hline NM & 0,86 & 1,00 & 1,00 & 0,00 & 0,35 & $-2,03$ & 5,12 & 612 & Yearly \\
\hline FOOD & 0,03 & 0,00 & 1,00 & 0,00 & 0,16 & 5,94 & 36,28 & 612 & Yearly \\
\hline CONSTRUCTION & 0,16 & 0,00 & 1,00 & 0,00 & 0,37 & 1,85 & 4,44 & 612 & Yearly \\
\hline INDUSTRY & 0,25 & 0,00 & 1,00 & 0,00 & 0,44 & 1,12 & 2,27 & 612 & Yearly \\
\hline LOGISTICS & 0,02 & 0,00 & 1,00 & 0,00 & 0,14 & 6,64 & 45,10 & 612 & Yearly \\
\hline REAL_ESTATE & 0,09 & 0,00 & 1,00 & 0,00 & 0,29 & 2,83 & 9,03 & 612 & Yearly \\
\hline RETAIL & 0,07 & 0,00 & 1,00 & 0,00 & 0,26 & 3,31 & 11,99 & 612 & Yearly \\
\hline SERVICES & 0,04 & 0,00 & 1,00 & 0,00 & 0,19 & 4,99 & 25,86 & 612 & Yearly \\
\hline TECHNOLOGY & 0,07 & 0,00 & 1,00 & 0,00 & 0,25 & 3,46 & 13,00 & 612 & Yearly \\
\hline UTILITIES & 0,19 & 0,00 & 1,00 & 0,00 & 0,40 & 1,54 & 3,38 & 612 & Yearly \\
\hline CRISIS & 0,12 & 0,00 & 1,00 & 0,00 & 0,32 & 2,40 & 6,75 & 612 & Yearly \\
\hline IPO_BOOM & 0,15 & 0,00 & 1,00 & 0,00 & 0,35 & 2,01 & 5,05 & 612 & Yearly \\
\hline
\end{tabular}

Once all the variables have been introduced, it is worth mentioning that variables representing similar financial information (for example, Net Fixed Asset Ratio 1 and 2 or logarithm of Size of Asset and logarithm Size of Revenue) will not be simultaneously included in the same regression since multicollinearity problems may arise. These variables are solely considered for the purpose of having alternative measures of the same influencing factor.

In that sense at least one variable of each group will be considered to estimate the regression, which should either confirm or neglect the significance of each coefficient as well as their expected signs.

In order to avoid multicollinearity issues, the correlation between selected variables had to be analyzed. It is worth mentioning that variables representing similar financial information will not be simultaneously included in the same regression since multicollinearity problems may arise. Among some variables that presented high correlation among each are Net Fixed Asset Ratio 1 and 2 or logarithm of Size of Asset and logarithm Size of Revenue, which presented, respectively, $\rho=0,82$ and $\rho=0,65$. These variables are solely considered for the 
purpose of having alternative measures of the same influencing factor. After the removal of such variables none of the others high correlation values $(\rho<0,65)$. Their simultaneous inclusion could compromise the precision of estimated coefficients and/or generate high standard errors (Gujarati, 2000), making any interpretation of the estimated model more difficult. While a good model allows for the interpretation of any estimated coefficient holding the others constant, such interpretation could not be so straight forward in the presence of multicollinearity. Any variability in one single variable could cause variation on another variable. Thus, individual influences could not be analyzed separately.

Table 6 reports the correlation for the selected variables obtained with the software Eviews. Except for the variables ofcf_capexand size_rev_ln, all other variables correlation with the dependent variable presented the expected signs.

\section{Table 6 - Correlation table}

This table provides pairwise correlations among the independent variables included in the empirical analysis: 1) Book to Market: book value of equity divided by market value of equity; 2) EBITDA over Financial Expenses: total EBITDA of the exercise divided by the amount of financial expenses; 3) Net Fixed Asset ratio 2: ratio between total fixed asset and equity; 4) ROA: Net income divided by total asset; 5) Operating Free Cash Flow over CAPEX: ratio between operating cash flow and amount dedicated to CAPEX; 6) Market Capitalization: logarithm of total volume of outstanding shares multiplied by the stock price of each period; 7) Size of Revenue: logarithm of total net revenue earned in a fiscal year; 8) Private Equity: dummy that assumes the value of one if PE/VC among shareholders and 0 otherwise; 9) ADR: dummy that assumes the value of 1 if company has ADR or 0 otherwise; 10) New Market: dummy that assumes the value of 1 if company is part of Bovespa's New Market or 0 otherwise; 11 to 19: dummy introduced for each type of industry that company belongs to, assuming the value of 1 if the company belongs to a specific industry or 0 otherwise; 21) Crisis year: dummy that assumes the value of 1 if financial information refer to 2008 or the value of 0 otherwise; 22) IPO Boom years: dummy that assumes the value of 1 if financial information refers to 2006 or 2007 and 0 otherwise.

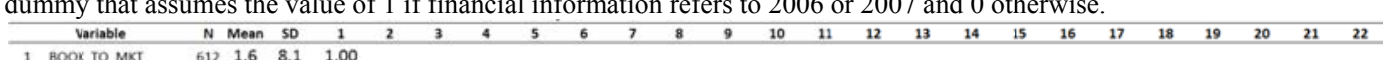

1 BOOK_TO_MKT $612 \quad 1,6 \quad 8,1 \quad 1,00$

\begin{tabular}{lllllll}
\hline EBITRA_FINEXP & 612 & 3,3 & 77,5 & $-0,06$ & 1,00
\end{tabular}

$\begin{array}{lllllll}\text { NetTXASSET_EquITY } & 612 & 0,7 & 1,2 & -0,02 & -0,03 & 1,00\end{array}$

$\begin{array}{llllllll}\text { NETHNCOME_ROA } 612 & 0,0 & 0,1 & -0,07 & 0,13 & -0,12 & 1,00\end{array}$

$\begin{array}{lllllllll}\text { OFCF_CAPEX } & 612 & 2,1 & 120,1 & 0,00 & -0,15 & 0,08 & -0,06 & 1,00\end{array}$

$\begin{array}{llllllllll}6 \text { SIZE_MV_LN } & 612 & 13,6 & 1,5 & -0,29 & 0,06 & 0,08 & 0,16 & -0,03 & 1,00\end{array}$

$\begin{array}{lllllllllll}\text { SIZE_REV_LN } & 612 & 13,1 & 1,5 & -0,23 & 0,06 & 0,15 & 0,23 & 0,01 & 0,51 & 1,00\end{array}$

$\begin{array}{llllllllllll}\text { PE } & 612 & 0,4 & 0,5 & -0,07 & -0,01 & -0,04 & 0,05 & -0,03 & 0,08 & 0,03 & 1,00\end{array}$

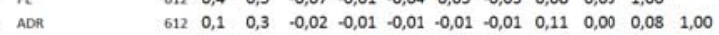

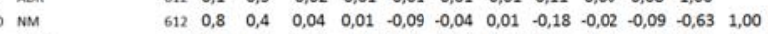

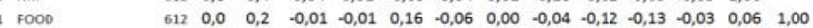

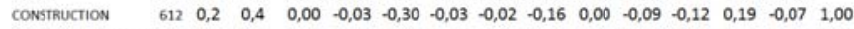

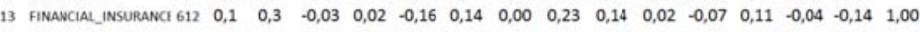

14 INOUSTRY $\quad \begin{array}{lllllllllllllllll}612 & 0,3 & 0,4 & -0,04 & -0,03 & 0,20 & -0,07 & -0,02 & 0,07 & 0,05 & 0,07 & -0,10 & 0,17 & -0,09 & -0,29 & -0,18 & 1,00\end{array}$

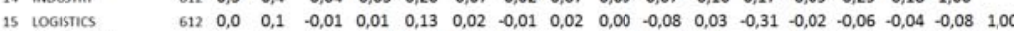

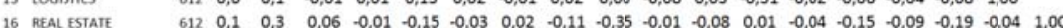

17 PeTAH

13 SERMCES

19 .

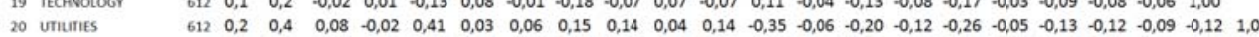

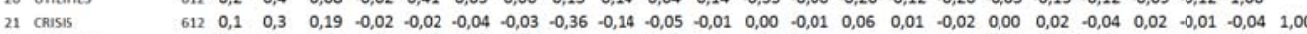

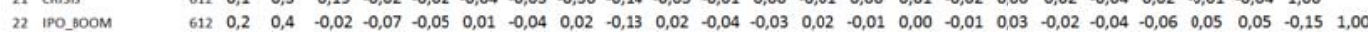

In that sense at least one variable of each group will be considered to estimate the following regression, which should either confirm or neglect the significance of each coefficient as well as their expected signs. 
$W A C C=\beta_{0}+\beta_{1 i t}(\text { NETFXASSET_EQUITY })_{i t}+\quad \beta_{2 i t}(\text { OFCF_CAPEX })_{i t}+$ $\beta_{3 i t}\left(E B I T D A \_F I N E X P\right)_{i t}{ }^{+} \quad \beta_{4 i t}\left(N E T I N C O M E \_R O A\right)_{i t}+$ $\beta_{5 i t}\left(B O O K \_T O_{-} M A R K E T\right)_{i t}+\quad \beta_{6 i t}\left(S I Z E \_M V \_L N\right)_{i t}+\quad \beta_{7 i t}\left(S I Z E \_R E V \_L N\right)_{i t}+$ $\beta_{8 i t}(P E)_{i t}+{ }_{\overline{9 i t}}(A D R)_{i t}+\quad \beta_{10 i t}(N M)_{i t}+\beta_{11 i t}^{-}$to 20it (Industry Dummy $)_{i t}+$ $\beta_{21 i t}\left(I P \beta_{-} B O O M\right)_{i t}+\beta_{22 i t}(C R I S I S)_{i t}+e_{i t}$

\subsection{Data Analysis Method}

Since the sample used contained data for both different years and different companies, it is structured as a panel data analysis. Given that some figures are missing for some companies and/or some years, such panel is an unbalanced one, with yearly figures from 2004 to 2013. After analyzing the correlation between the suggested variables, they were submitted to Least Squares regression analysis, using the software Eviews. Special attention was given to control for any autocorrelation and heteroskedasticity issues. The software version of Eviews does not perform specific tests for heteroskedasticity on panel data, but allows the user to control for them. The risk for the later issue is even more evident given the amplitude of values observed for some variables, as above mentioned (ebitda_finexp, book_to_mktand ofcf_capex). Analyzed data very likely contains different cross section variability. For the estimation of Best Linear Unbiased Estimators (BLUE), it would be wise to attach more weight to lower variability sections, which are more closely distributed around mean values (GUJARATI, 2000). In that sense, instead of using the Ordinary Least Squares (OLS) method to estimate the regression, the Generalized Least Squares (GLS) method was applied with White's cross section weights and White's cross section control for coefficient covariance. Such procedure assures the estimation of more precise coefficients as well as model fit tests and final results of significantly higher accuracy.

As stated by Brooks (2008), in case errors of the regression are heteroscedastic, the use of Ordinary Least Squares will still provide unbiased and consistent estimators. However, their variance will no longer be minimum and standard errors could be too large, risking any inference based on the available sample. In order to address such problem sample must be adjusted to the criteria required by 
OLS estimation. This is what the Generalized Least Squares (GLS) method, also known as Weighted Least Squares (WLS), does to the sample: following White's (1980, APUD BROOKS, 2008) method, the use of different weights according to the variability of the sections of the sample will help minimize the sum of squared errors, enabling minimum variance.

Apart from heteroskedasticity, on the event of auto-correlation, not only across the time series of variables but also across companies, estimated variances could be potentially disturbed, compromising all the statistics used to test the model (GUJARATI, 2000). For that matter, the analysis also benefits a great deal from the introduction of White's method to control for heteroskedasticity. The use of GLS also addresses auto-correlation issues, improving the results.

Model robustness tests checked for fixed and random effects that could possibly compromise the results. In order to identify any possible fixed effects that could be found in the results due to either use of yearly or cross section information, the redundant fixed effects was applied, rejecting the presence of fixed effects of any kind. However, the use of Hausman test to the complete model raised strong evidence of random effects. For that matter, the model specification was adjusted to control for cross-section random effects, in detriment of the GLS model. 


\section{Regression Results}

In order to test the influence of the independent variables, different sets of variables were introduced in seven different estimation rounds. The first of them, model (1), included the financial variables. On the second model (2), 10 industry dummy variables are introduced. Model (3) introduces a dummy for the studied variable, PE/VC. Model (4),(5) and (6) introduced dummy variables for ADR and Bovespa's New Market. Each one is introduced separately for models (4) and (5), while model (6) includes both simultaneously. The most complete regression, model (7), introduces a dummy variable to control for information from 2006 and 2007, years of significant increase in the number of IPO's, and a dummy to control for the effects of the financial crisis in 2008. The 7 different models are detailed below. Table 7 contains the results obtained for each model, as well as significance statistics for each one.

$W A C C=\beta_{0}+\beta_{1 i t}(\text { netfxasset_equity })_{i t}+\beta_{2 i t}(\text { ofcf_capex })_{i t}+\beta_{3 i t}(\text { ebitda_finexp })_{i t}+$ $\beta_{4 i t}(\text { netincome_roa })_{i t}+\beta_{5 i t}(\text { book_to_market })_{i t}+\bar{\beta}_{6 i t}(\text { size_mv_ln })_{i t}+\beta_{7 i t}(\text { size_rev_ln })_{i t}+$ $e_{i t}$

$W A C C=\beta_{0}+\beta_{\text {Iit }}(\text { netfxasset_equity })_{i t}+\beta_{2 i t}(\text { ofcf_capex })_{i t}+\beta_{3 i t}(\text { ebitda_finexp })_{i t}+$ $\beta_{4 i t}(\text { netincome_roa })_{i t}+\beta_{5 i t}(\text { book_to_market })_{i t}+\bar{\beta}_{6 i t}(\text { size_mv_ln })_{i t}+\beta_{7 i t}(\text { size_rev_ln })_{i t}+$ $\beta_{\text {8it to 17it }}$ (industry dummy) ${ }_{i t}+e_{i t}$

$W A C C=\beta_{0}+\beta_{\text {lit }}$ (netfxasset_equity $)_{i t}+\beta_{2 i t}(\text { ofcf_capex })_{i t}+\beta_{3 i t}(\text { ebitda_finexp })_{i t}+$ $\beta_{4 i t}(\text { netincome_roa })_{i t}+\beta_{5 i t}(\text { book_to_market })_{i t}+\bar{\beta}_{6 i t}(\text { size_mv_ln })_{i t}+\beta_{7 i t}(\text { size_rev_ln })_{i t}+$ $\beta_{\text {8it }}(\text { pe })_{i t}+\beta_{9 i t \text { to } 18 i t}\left(\right.$ industry dummy) ${ }_{i t}+e_{i t}$

$W A C C=\beta_{0}+\beta_{1 i t}(\text { netfxasset_equity })_{i t}+\beta_{2 i t}(\text { ofcf_capex })_{i t}+\beta_{3 i t}(\text { ebitda_finexp })_{i t}+$ $\beta_{4 i t}(\text { netincome_roa })_{i t}+\beta_{5 i t}(\text { book_to_market })_{i t}+\bar{\beta}_{6 i t}(\text { size_mv_ln })_{i t}+\beta_{7 i t}(\text { size_rev_ln })_{i t}+$

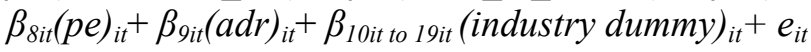

$W A C C=\beta_{0}+\beta_{1 i t}(\text { netfxasset_equity })_{i t}+\beta_{2 i t}(\text { ofcf_capex })_{i t}+\beta_{3 i t}(\text { ebitda_finexp })_{i t}+$ $\beta_{4 i t}(\text { netincome_roa })_{i t}+\beta_{5 i t}(\text { book_to_market })_{i t}+\bar{\beta}_{6 i t}(\text { size_mv_ln })_{i t}+\beta_{7 i t}(\text { size_rev_ln })_{i t}+$

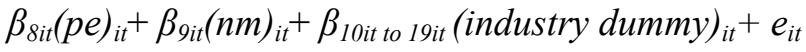

$W A C C=\beta_{0}+\beta_{1 i t}(\text { netfxasset_equity })_{i t}+\beta_{2 i t}(\text { ofcf_capex })_{i t}+\beta_{3 i t}(\text { ebitda_finexp })_{i t}+$ $\beta_{4 i t}(\text { netincome_roa })_{i t}+\beta_{5 i t}(\text { book_to_market })_{i t}+\bar{\beta}_{6 i t}(\text { size_mv_ln })_{i t}+\beta_{7 i t}(\text { size_rev_ln })_{i t}+$ $\beta_{8 i t}(\text { pe })_{i t}+\beta_{9 i t}(\overline{a d r})_{i t}+\beta_{10 i t}(\mathrm{~nm})_{i t}+\beta_{1 \text { lit to 20it }}$ (industry dummy) $)_{i t}+e_{i t}$ 
$W A C C=\beta_{0}+\beta_{1 i t}(\text { netfxasset_equity })_{i t}+\beta_{2 i t}(\text { ofcf_capex })_{i t}+\beta_{3 i t}(\text { ebitda_finexp })_{i t}+$ $\beta_{4 i t}(\text { netincome_roa })_{i t}+\beta_{5 i t}(\text { book_to_market })_{i t}+\beta_{6 i t}(\text { size_mv_ln })_{i t}+\beta_{7 i t}(\text { size_rev_ln })_{i t}+$ $\beta_{8 i t}(\text { pe })_{i t}+\beta_{9 i t}(\text { adr })_{i t}+\beta_{10 i t}(\mathrm{~nm})_{i t}+\beta_{1 \text { lit to 20it }}$ (industrydummy) ${ }_{i t}+\beta_{21 i t}\left(\right.$ ipo_boom) ${ }_{i t}+\beta_{22 i t}$ $(\text { crisis) })_{i t}+e_{i t}$ 
Table 7 - Estimated regression

D.V.: Dependent variable. Independent variables: 1) Net Fixed Asset ratio 2: ratio between total fixed asset and equity; 2) Operating Free Cash Flow over CAPEX: ratio between operating cash flow and amount dedicated to CAPEX; 3) EBITDA over Financial Expenses: total EBITDA of the exercise divided by the amount of financial expenses; 4) ROA: Net income divided by total asset; 5) Book to Market: book value of equity divided by market value of equity; 6) Market Capitalization: logarithm of total volume of outstanding shares multiplied by the stock price of each period; 7) Size of Revenue: logarithm of total net revenue earned in a fiscal year; 8) Private Equity: dummy that assumes the value of one if $\mathrm{PE} / \mathrm{VC}$ among shareholders and 0 otherwise; 9) ADR: dummy that assumes the value of 1 if company has ADR or 0 otherwise; 10) New Market: dummy that assumes the value of 1 if company is part of Bovespa's New Market or 0 otherwise; 11 to 19: dummy introduced for each type of industry that company belongs to, assuming the value of 1 if the company belongs to a specific industry or 0 otherwise; 20) IPO Boom years: dummy that assumes the value of 1 if financial information refers to 2006 or 2007 and 0 otherwise; 21) Crisis year: dummy that assumes the value of 1 if financial information refer to 2008 or the value of 0 otherwise.

All coefficients are obtained by estimating random-effects panel data model. Data include yearly information for 129 companies from 2004 to 2013 . Heteroskedasticity consistent standard errors clustered are reported in parentheses. *, **, and $* * *$ represent statistical significance at the $10 \%, 5 \%$, and $1 \%$ level, respectively. Source: data analysis.

\begin{tabular}{|c|c|c|c|c|c|c|c|}
\hline \multicolumn{8}{|c|}{ D.V.: Weighted average cost of capital } \\
\hline Coefficients & Model 1 & Model 2 & Model 3 & Model 4 & Model 5 & Model 6 & Model 7 \\
\hline Constant & $\begin{array}{c}0,275^{* * * *} \\
(0,042)\end{array}$ & $\begin{array}{c}0,299^{* * * *} \\
(0,056)\end{array}$ & $\begin{array}{c}0,297 * * * \\
(0,057)\end{array}$ & $\begin{array}{c}0,293^{* * *} \\
(0,058)\end{array}$ & $\begin{array}{c}0,310 * * * \\
(0,054)\end{array}$ & $\begin{array}{c}0,328^{* * * *} \\
(0,050)\end{array}$ & $\begin{array}{l}0,142^{*} \\
(0,077)\end{array}$ \\
\hline \multicolumn{8}{|c|}{ Explanatory variables } \\
\hline \multicolumn{8}{|c|}{ Financial Variables } \\
\hline netfixasset_equity & $\begin{array}{l}0,013^{*} \\
(0,007)\end{array}$ & $\begin{array}{c}0,009 \\
(0,007)\end{array}$ & $\begin{array}{c}0,009 \\
(0,007)\end{array}$ & $\begin{array}{c}0,009 \\
(0,007)\end{array}$ & $\begin{array}{c}0,009 \\
(0,007)\end{array}$ & $\begin{array}{c}0,009 \\
(0,007)\end{array}$ & $\begin{array}{c}0,010 \\
(0,006)\end{array}$ \\
\hline ofcf_capex & $\begin{array}{c}0,000 \\
(0,000)\end{array}$ & $\begin{array}{c}0,000 \\
(0,000)\end{array}$ & $\begin{array}{c}0,000 \\
(0,000)\end{array}$ & $\begin{array}{c}0,000 \\
(0,000)\end{array}$ & $\begin{array}{c}0,000 \\
(0,000)\end{array}$ & $\begin{array}{c}0,000 \\
(0,000)\end{array}$ & $\begin{array}{c}0,000 \\
(0,000)\end{array}$ \\
\hline ebitda finexp & $\begin{array}{c}0,000^{* * *} \\
(0,000)\end{array}$ & $\begin{array}{c}0,000^{* * * *} \\
(0,000)\end{array}$ & $\begin{array}{c}0,000^{* * *} \\
(0,000)\end{array}$ & $\begin{array}{c}0,000^{* * *} \\
(0,000)\end{array}$ & $\begin{array}{c}0,000^{* * *} \\
(0,000)\end{array}$ & $\begin{array}{c}0,000^{* * * *} \\
(0,000)\end{array}$ & $\begin{array}{c}0,000^{* * * *} \\
(0,000)\end{array}$ \\
\hline roa & $\begin{array}{c}-0,040^{* *} \\
(0,015)\end{array}$ & $\begin{array}{c}-0,039^{* * *} \\
(0,015)\end{array}$ & $\begin{array}{c}-0,040^{* * * *} \\
(0,014)\end{array}$ & $\begin{array}{c}-0,041^{\text {********* }} \\
(0,015)\end{array}$ & $\begin{array}{c}-0,039^{* \cdots *} \\
(0,014)\end{array}$ & $\begin{array}{c}-0,041 \\
(0,014)\end{array}$ & $\begin{array}{c}-0,056^{* * * *} \\
(0,017)\end{array}$ \\
\hline book to $\mathrm{mkt}$ & $\begin{array}{c}-0,001^{* * *} \\
(0,000)\end{array}$ & $\begin{array}{c}-0,001^{* * * *} \\
(0,000)\end{array}$ & $\begin{array}{c}-0,001^{* * * *} \\
(0,000)\end{array}$ & $\begin{array}{c}-0,001^{* * * *} \\
(0,000)\end{array}$ & $\begin{array}{c}-0,001^{* * * *} \\
(0,000)\end{array}$ & $\begin{array}{c}-0,001^{* * *} \\
(0,000)\end{array}$ & $\begin{array}{c}0,000^{* *} \\
(0,000)\end{array}$ \\
\hline size $m v \ln$ & $\begin{array}{c}-0,013^{* * *} \\
(0,003)\end{array}$ & $\begin{array}{c}-0,014 * * * * \\
(0,004)\end{array}$ & $\begin{array}{c}-0,014 * * * * \\
(0,004)\end{array}$ & $\begin{array}{c}-0,014^{* * * *} \\
(0,004)\end{array}$ & $\begin{array}{c}-0,015^{* * * *} \\
(0,004)\end{array}$ & $\begin{array}{c}-0,014 * * * \\
(0,004)\end{array}$ & $\begin{array}{c}-0,009^{* *} \\
(0,004)\end{array}$ \\
\hline size rev $\ln$ & $\begin{array}{c}0,000 \\
(0,002)\end{array}$ & $\begin{array}{c}0,002 \\
(0,004)\end{array}$ & $\begin{array}{c}0,002 \\
(0,004)\end{array}$ & $\begin{array}{c}0,001 \\
(0,004)\end{array}$ & $\begin{array}{c}0,002 \\
(0,004)\end{array}$ & $\begin{array}{c}0,002 \\
(0,004)\end{array}$ & $\begin{array}{c}0,009^{* * *} \\
(0,002)\end{array}$ \\
\hline \multicolumn{8}{|l|}{ Focus variable } \\
\hline pe & & & $\begin{array}{c}0,008 \\
(0,007)\end{array}$ & $\begin{array}{c}0,011 \\
(0,007)\end{array}$ & $\begin{array}{c}0,007 \\
(0,006)\end{array}$ & $\begin{array}{c}0,010 \\
(0,006)\end{array}$ & $\begin{array}{l}0,010^{*} \\
(0,006)\end{array}$ \\
\hline \multicolumn{8}{|c|}{ Market insertion variables } \\
\hline$a d r$ & & & & $\begin{array}{c}-0,033^{* * * *} \\
(0,009)\end{array}$ & & $\begin{array}{c}-0,061^{* * * *} \\
(0,018)\end{array}$ & $\begin{array}{c}-0,057^{* * *} \\
(0,016)\end{array}$ \\
\hline$n m$ & & & & & $\begin{array}{c}-0,012 \\
(0,010)\end{array}$ & $\begin{array}{c}-0,038^{* *} \\
(0,016)\end{array}$ & $\begin{array}{c}-0,034^{* * *} \\
(0,017)\end{array}$ \\
\hline \multicolumn{8}{|c|}{ Market registration variables } \\
\hline industry & & $\begin{array}{c}0,004 \\
(0,016)\end{array}$ & $\begin{array}{c}0,004 \\
(0,016)\end{array}$ & $\begin{array}{c}0,005 \\
(0,017)\end{array}$ & $\begin{array}{c}0,003 \\
(0,016)\end{array}$ & $\begin{array}{c}0,003 \\
(0,016)\end{array}$ & $\begin{array}{c}0,012 \\
(0,014)\end{array}$ \\
\hline utilities & & $\begin{array}{c}-0,006 \\
(0,019)\end{array}$ & $\begin{array}{c}-0,007 \\
(0,019)\end{array}$ & $\begin{array}{c}-0,002 \\
(0,019)\end{array}$ & $\begin{array}{c}-0,012 \\
(0,017)\end{array}$ & $\begin{array}{l}-0,014 \\
(0,015)\end{array}$ & $\begin{array}{c}-0,011 \\
(0,014)\end{array}$ \\
\hline food & & $\begin{array}{c}0,007 \\
(0,029)\end{array}$ & $\begin{array}{c}0,010 \\
(0,029)\end{array}$ & $\begin{array}{c}0,012 \\
(0,028)\end{array}$ & $\begin{array}{c}0,009 \\
(0,029)\end{array}$ & $\begin{array}{c}0,011 \\
(0,028)\end{array}$ & $\begin{array}{c}0,030 \\
(0,029)\end{array}$ \\
\hline retail & & $\begin{array}{l}-0,016 \\
(0,013)\end{array}$ & $\begin{array}{l}-0,017 \\
(0,013)\end{array}$ & $\begin{array}{l}-0,013 \\
(0,014)\end{array}$ & $\begin{array}{c}-0,018 \\
(0,012)\end{array}$ & $\begin{array}{c}-0,014 \\
(0,013)\end{array}$ & $\begin{array}{c}-0,005 \\
(0,007)\end{array}$ \\
\hline construction & & $\begin{array}{c}-0,048^{* * *} \\
(0,012)\end{array}$ & $\begin{array}{c}-0,047^{* * *} \\
(0,013)\end{array}$ & $\begin{array}{c}-0,046^{* * * *} \\
(0,013)\end{array}$ & $\begin{array}{c}-0,047^{* * *} \\
(0,013)\end{array}$ & $\begin{array}{c}-0,046^{* * *} \\
(0,013)\end{array}$ & $\begin{array}{c}-0,038^{* * *} \\
(0,009)\end{array}$ \\
\hline technology & & $\begin{array}{l}-0,026 \\
(0,019)\end{array}$ & $\begin{array}{c}-0,028 \\
(0,018)\end{array}$ & $\begin{array}{l}-0,028 \\
(0,018)\end{array}$ & $\begin{array}{c}-0,028 \\
(0,018)\end{array}$ & $\begin{array}{c}-0,027 \\
(0,018)\end{array}$ & $\begin{array}{c}-0,013 \\
(0,014)\end{array}$ \\
\hline real estate & & $\begin{array}{c}-0,018 \\
(0,029)\end{array}$ & $\begin{array}{c}-0,018 \\
(0,030)\end{array}$ & $\begin{array}{c}-0,018 \\
(0,030)\end{array}$ & $\begin{array}{c}-0,019 \\
(0,029)\end{array}$ & $\begin{array}{c}-0,021 \\
(0,028)\end{array}$ & $\begin{array}{c}0,000 \\
(0,022)\end{array}$ \\
\hline logistics & & $\begin{array}{c}-0,037^{* *} \\
(0,015)\end{array}$ & $\begin{array}{c}-0,037^{* *} \\
(0,015)\end{array}$ & $\begin{array}{l}-0,021 \\
(0,014)\end{array}$ & $\begin{array}{c}-0,049^{* * * *} \\
(0,012)\end{array}$ & $\begin{array}{c}-0,046^{* * *} \\
(0,011)\end{array}$ & $\begin{array}{c}-0,043^{* * *} \\
(0,014)\end{array}$ \\
\hline services & & $\begin{array}{c}0,002 \\
(0,025)\end{array}$ & $\begin{array}{c}0,004 \\
(0,026)\end{array}$ & $\begin{array}{c}0,018 \\
(0,025)\end{array}$ & $\begin{array}{l}-0,002 \\
(0,027)\end{array}$ & $\begin{array}{c}0,008 \\
(0,026)\end{array}$ & $\begin{array}{c}0,024 \\
(0,022)\end{array}$ \\
\hline \multicolumn{8}{|c|}{ Macroeconomic Circumstances } \\
\hline ipo boom & & & & & & & $\begin{array}{c}0,042^{* * * *} \\
(0,006)\end{array}$ \\
\hline crisis & & & & & & & $\begin{array}{c}0,045^{* * * *} \\
(0,007)\end{array}$ \\
\hline Observations & 612 & 612 & 612 & 612 & 612 & 612 & 612 \\
\hline F-statistic & $9,712^{* * *}$ & $5,476 * * *$ & $5,210^{* * *}$ & $5,130^{* * *}$ & $4,966 * * *$ & $5,210^{* * *}$ & $9,967 * * *$ \\
\hline R-squared & 0,101 & 0,128 & 0,130 & 0,135 & 0,131 & 0,143 & 0,262 \\
\hline Adjusted $\mathrm{R}^{2}$ & 0,091 & 0,105 & 0,105 & 0,108 & 0,105 & 0,116 & 0,236 \\
\hline$\Delta \mathrm{R}^{2}$ & & 0,014 & 0,000 & 0,003 & $-0,003$ & 0,011 & 0,120 \\
\hline
\end{tabular}


Model 1 estimated the coefficients of the financial group of variables. With a significant F-statistic, 6 of the 8 coefficients are significant, 4 of them at the $1 \%$ level of significance, one at the $5 \%$ level and one at the $10 \%$ level. The coefficients obtained for $r o a, b o o k \_t o \_m k t a n d$ size_mv_lnnot only are significant, but also presented the expected sign. Results suggest a negative influence on WACC from such variables. Also significant, netfxasset_equityresulting coefficient is positive, as expected. The amount of capital immobilized may have a positive influence on WACC.

The influence from the relationship between EBITDA and the financial expenses resulted null, despite the statistical significance. The variable ofcf_capexalso resulted null and did not prove significant to explain the dependent variable. Nullity put aside, the lack of significance suggests the amount of cash flow relative to the amount of cash committed to CAPEX does not influence the cost of capital. Apart from cash flow, size_rev_lnis not significant across most of the specifications. Expected sign for that variable was negative and it turned out positive throughout all specifications. Since such variable is the logarithm of a company's revenue, the coefficient suggests positive revenue variation increases cost of capital. It could be the case that companies' revenues marginal increments may be decreasing over the studied years, with an impact on the perception of risk.

The second model introduces dummy variables to control for the industry a company belongs to. Altogether, 10 different industry types were considered. Results obtained for the financial variables were very similar to the first regression, although netfxasset_equityresulted not significant in this model. The coefficient obtained for $r o a$, on the other hand, became significant at the $1 \%$ level (compared to significance at 5\% in model 1). Only dummy variables for industries of construction and logistics are significant, the first at the $1 \%$ and the later at the $5 \%$ level. This result is fairly consistent across all estimated models and may suggest some industries play more significant roles in the financial market, either because of the amounts involved in each transaction or due to more specific characteristics of an industry's capital structure. 
The introduction of a dummy for PE/VC in the third model did not influence the explanatory power of the previous model, as suggested by the Adjusted $\mathrm{R}^{2}$.It is worth mentioning that almost all the significant variables remained practically unchanged compared to model 2.

An important outcome regards the focus variable introduced in this study. The dummy introduced to control for the presence of PE/VC-backed companies was positive but not significant. It was previously mentioned that the expected effect of this variable was uncertain. Intuitively, it could be expected that the presence of $\mathrm{PE} / \mathrm{VC}$ funds could contribute to improve managerial performance, professionalization, better network and many other benefits for invested companies, thus potentially reducing the risk and cost of capital. However the results obtained in the third regression model suggest otherwise, that is, the presence of $\mathrm{PE} / \mathrm{VC}$ funds among shareholders does not influence the cost of capital.

Differing from the third model, the introduction of dummy variables to control for companies' ADR adds explanatory power to the fourth model. The estimated coefficient, significant at the $1 \%$ level, presented the expected negative sign, suggesting ADR's may reduce WACC. Such influence pattern may result from the fact that this form of interaction with the market reduces the perceived risk by increasing information disclosure, adherence to international accounting procedures, among other practices. While increasing in absolute value, the focus variable, pe, remains not significant in this model. Additionally, the dummy variable introduced for the logistics industry loses its significance.

Results for model 5 suggest a small loss in explanatory power, as suggested by the adjusted $\mathrm{R}^{2}$ of 0,105 , smaller than in model 4 . Instead of controlling for ADR's, model 5controls for companies' presence in Bovespa's new market. The dummy variable introduced for that purpose assumes the value of 1 if companies are part of the new market or 0 otherwise. The estimated coefficient was not significant. In other words, complying with corporate governance practices of the new market does not seem to influence the cost of capital. 
Following from the results observed in model 5, both ADR and new market dummy variables are used in model 6 . One interesting result noticed was that both coefficients present nearly twice as much influence on WACC as was observed in models 4 and 5.Also, controlling for $a d r$ and $\mathrm{nm}$ simultaneously does not have any impact on either the coefficient or the significance of the pedummy variable. No significant change is observed for any financial variable, compared to the other models.

Model 7 differs from the previous models in that two macroeconomic variables are introduced. The first of them, IPO Boom years controls for observations that belong to 2006 and 2007, years that witnessed a significant number of Brazilian companies going public. Additionally, a dummy is introduced to account for the year of 2008, when the most recent financial crisis reached one of its most influential periods. The overall significance of the model improves with a simultaneous increase in the explanatory power.

Contrary to the other specifications, peis significant at the $10 \%$ level in model 7 , suggesting it has some influence on WACC. With a positive sign it could be the case that the presence of $\mathrm{PE} / \mathrm{VC}$ funds among shareholders may actually increase the cost of capital. Proper scrutiny of this result requires further analysis of the individual components of cost of capital. However, it could be the case that the presence of $\mathrm{PE} / \mathrm{VC}$ funds among shareholders actually influences cost of equity and cost of debt differently. On one hand, PE/VC funds may in fact introduce a number of benefits to invested companies, increasing the overall return on equity, which is the same as increasing the cost of equity. On the other hand, PE/VC may increase the managerial capacity of invested companies, thus, reducing the perceived risk and influencing the cost of debt.

Along with pe, both ipo_boomand crisis are significant at the $1 \%$ level. IPO Boom yearspresents a positive sign, opposite to what was expected. Such result is surprising since 2006 and 2007 supposedly presented a more favorable environment for companies to go public.

It does not seem to be the case. Instead, part of the explanation for the positive influence over the cost of capital may be nested on the very same dynamics that 
cause $\mathrm{PE} / \mathrm{VC}$ funds participation to raise the cost of capital. In other words, while representing favorable circumstances to go public, 2006 and 2007 may have been years of greater return on invested capital, thus increasing the overall cost of capital.

Two changes are worth mentioning for model 7. Despite the lack of significance throughout all other specifications, size_rev_lnbecomes significant at the $1 \%$ level in the complete model. The resulting sign, however, does not conform with what was expected: it suggests the size of the revenue actually increases WACC. As mentioned, it could be the case that companies' revenues marginal increments may be decreasing over the studied years, with an impact on the perception of risk.

Apart from the specifications analyzed, it could be the case that some variables included in the models present some sort of interactive influence on WACC. In other words, two variables might be producing an aggregate effect on WACC with a magnitude higher than the sum of the individual influences. In order to test for this case three possibilities of interaction were analyzed with the use of three specific dummy variables, namely PE/VC, New Market and IPO Boom. Model 7a introduces a dummy variable to control for the influence of PE/VC combined with the influence of participating in Bovespa's new market. The hypothesis under analysis is that being an invested company and participating on Bovespa's new market reduces the cost of capital. The coefficient for this estimate is, thus, expected to present a negative sign. Model $7 \mathrm{~b}$ replaces the new market dummy variable for that of IPO Boom, suggesting that being an invested company during 2006 and 2007 could be beneficial in terms of cost reduction. Expected sign for this estimate is also negative. Finally, model 7c addresses both possibilities simultaneously, that is, being an invested company and a member of the new market while being an invested company during 2006 and 2007.The additional regression models are the detailed below:

$W A C C=\beta_{0}+\beta_{1 i t}(\text { netfxasset_equity })_{i t}+\beta_{2 i t}(\text { ofcf_capex })_{i t}+\beta_{3 i t}(\text { ebitda_finexp })_{i t}+$ $\beta_{\text {4it }}(\text { netincome_roa })_{i t}+\beta_{5 i t}(\text { book_to_market })_{i t}+\bar{\beta}_{6 i t}(\text { size_mv_ln })_{i t}+\beta_{7 i t}(\text { size_rev_ln })_{i t}+$ $\beta_{8 i t}(\text { pe })_{i t}+\beta_{9 i t}(\overline{a d r})_{i t}+\beta_{10 i t}(n m)_{i t}+\beta_{11 i t \text { to 20it }}$ (industry dummy) $)_{i t}+\beta_{21 i t}(\text { ipo_boom })_{i t}+\beta_{22 i t}$ $\left(\right.$ crisis) ${ }_{i t}+e_{i t}$ 
$W A C C=\beta_{0}+\beta_{1 i t}(\text { netfxasset_equity })_{i t}+\beta_{2 i t}(\text { ofcf_capex })_{i t}+\beta_{3 i t}(\text { ebitda_finexp })_{i t}+$ $\beta_{\text {4it }}(\text { netincome_roa })_{i t}+\beta_{5 i t}(\text { book_to_market })_{i t}+\beta_{6 i t}(\text { size_mv_ln })_{i t}+\beta_{7 i t}(\text { size_rev_ln })_{i t}+$

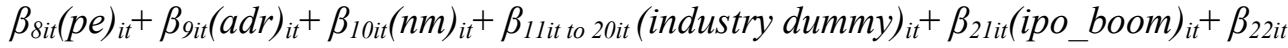

$(\text { crisis })_{i t}+\beta_{23 i t}($ pe $) *(n m)_{i t}+e_{i t}$

$W A C C=\beta_{0}+\beta_{1 i t}(\text { netfxasset_equity })_{i t}+\beta_{2 i t}(\text { ofcf_capex })_{i t}+\beta_{3 i t}(\text { ebitda_finexp })_{i t}+$ $\beta_{4 i t}(\text { netincome_roa })_{i t}+\beta_{5 i t}(\text { book_to_market })_{i t}+\bar{\beta}_{6 i t}(\text { size_mv_ln })_{i t}+\beta_{7 i t}(\text { size_rev_ln })_{i t}+$ $\beta_{8 i t}(\text { pe })_{i t}+\beta_{9 i t}(\overline{a d r})_{i t}+\beta_{10 i t}(\mathrm{~nm})_{i t}+\beta_{11 \text { it to 20it }}$ (industry dummy) $)_{i t}+\beta_{21 i t}(\text { ipo_boom) })_{i t}+\beta_{22 i t}$ $(\text { crisis) })_{i t}+\beta_{23 i t}($ pe $) *(\text { ipo_boom })_{i t}+e_{i t}$

$W A C C=\beta_{0}+\beta_{1 i t}(\text { netfxasset_equity })_{i t}+\beta_{2 i t}(\text { ofcf_capex })_{i t}+\beta_{3 i t}(\text { ebitda_finexp })_{i t}+$ $\beta_{4 i t}(\text { netincome_roa })_{i t}+\beta_{5 i t}(\text { book_to_market })_{i t}+\bar{\beta}_{6 i t}(\text { size_mv_ln })_{i t}+\beta_{7 i t}(\text { size_rev_ln })_{i t}+$

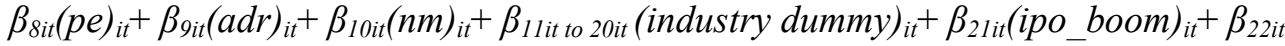
$(\text { crisis })_{i t}+\beta_{23 i t}($ pe $) *(n m)_{i t}++\beta_{24 i t}($ pe $) *(\text { ipo_boom })_{i t}+e_{i t}$

Results from this new set of estimations can be found in table 8. Following model 7 results, peis significant at the $10 \%$ level, with a positive sign. The same financial variables are significant in every new estimated model. Three variables, namely ebitda_finexp, roaand size_rev_ln, are significant at the $1 \%$ level for models $\mathrm{a}, \mathrm{b}$ and $\mathrm{c}$, with barely any variance in the coefficient value. Book_to_mkt is consistently significant at the 5\% level and size_mv_lnis significant at the 5\% level for model $7 \mathrm{~b}$, and significant at the $1 \%$ level for model a and c. Such variance in this later variable's significance may have to do with the introduction of the interaction between peand $\mathrm{nm}$, which might have contributed to increase its explanatory power.

However, the interaction of peand $\mathrm{nm}$ is not significant for both models $7 \mathrm{a}$ and $7 \mathrm{c}$. It was expected that $\mathrm{PE} / \mathrm{VC}$-backed companies that belong to Bovespa's new market face a cost of capital lower than companies that are not PE/VC backed and are not part of the new market. One possible explanation for this could be the fact that both contexts favor the implementation and use of good practices of corporate governance. In that sense, management in firms that fit into this situation would tend to be more efficient, tackling emerging risks and fostering new business opportunities. Since the observed sign corresponds to what was expected, results suggested an interactive influence of these two variables on WACC. The fact that the variable is not significant suggests otherwise, that is, being PE/VC backed and part of the new market does not influence WACC. An interesting point observed in this model is that $\mathrm{nm}$ alone is also not significant. It seems like the introduction 
of an interactive variable may have affected the explanatory power of that variable.

With regards to the possibility embedded in model $7 \mathrm{~b}$ (being an invested company during 2006 and 2007), regression results show that the coefficient that responds for the interaction between PE/VC and IPO Boom is significant at the 5\% level. Nevertheless, the resulting coefficient sign does not correspond to what was expected. Like that of IPO Boom individually, the coefficient addressing the interactive variables may in fact increase WACC by almost $1 \%$. As before, if 2006 and 2007 were good years for IPO's and if it is true that PE/VC increases return on equity, it could be the case that the return of these two circumstances combined can produce the same impact on the cost of equity and as a consequence increase WACC. Finally, even though the interaction between peand ipo_boom is significant, pealone is not.

Model $7 \mathrm{c}$ tries to estimate the sum of the impacts of these two combinations, by introducing one dummy variable to the interaction PE/VC_New Market and one dummy variable to the interaction PE/VC_IPO Boom. Results obtained show that not only pe, but also $\mathrm{nm}$ and the interaction between peand $\mathrm{nm}$ are not significant at any level. If anything, the introduction of an interaction between peand $\mathrm{nm}$ may be accounted for increasing ADR's coefficient value and reducing that of $\mathrm{nm}$. Finally, that interaction may also have to do with the statistical significance of services. 


\section{Table 8 - Estimated regression with interactive effect}

D.V.: Dependent variable. Independent variables: 1) Net Fixed Asset ratio 2: ratio between total fixed asset and equity; 2) Operating Free Cash Flow over CAPEX: ratio between operating cash flow and amount dedicated to CAPEX; 3) EBITDA over Financial Expenses: total EBITDA of the exercise divided by the amount of financial expenses; 4) ROA: Net income divided by total asset; 5) Book to Market: book value of equity divided by market value of equity; 6) Market Capitalization: logarithm of total volume of outstanding shares multiplied by the stock price of each period; 7) Size of Revenue: logarithm of total net revenue earned in a fiscal year; 8) Private Equity: dummy that assumes the value of one if PE/VC among shareholders and 0 otherwise; 9) ADR: dummy that assumes the value of 1 if company has ADR or 0 otherwise; 10) New Market: dummy that assumes the value of 1 if company is part of Bovespa's New Market or 0 otherwise; 11 to 19: dummy introduced for each type of industry that company belongs to, assuming the value of 1 if the company belongs to a specific industry or 0 otherwise; 20) IPO Boom years: dummy that assumes the value of 1 if financial information refers to 2006 or 2007 and 0 otherwise; 21) Crisis year: dummy that assumes the value of 1 if financial information refer to 2008 or the value of 0 otherwise.

All coefficients are obtained by estimating random-effects panel data model. Industry dummies are included in each regression but are not reported. Data include yearly information for 129 companies from 2004 to 2013. Heteroskedasticity consistent standard errors clustered are reported in parentheses. *,**, and *** represent statistical significance at the $10 \%$, $5 \%$, and $1 \%$ level, respectively.Source: data analysis.

\begin{tabular}{|c|c|c|c|c|}
\hline \multicolumn{5}{|c|}{ D.V.: Weighted average cost of capital } \\
\hline Coefficients & Model 7 & Model 7a & Model 7b & Model 7c \\
\hline Constant & $\begin{array}{l}0,142^{*} \\
(0,077)\end{array}$ & $\begin{array}{c}0,131 \\
(0,081)\end{array}$ & $\begin{array}{l}0,145^{*} \\
(0,076)\end{array}$ & $\begin{array}{l}0,133^{*} \\
(0,080)\end{array}$ \\
\hline \multicolumn{5}{|l|}{ Explanatory variables } \\
\hline \multicolumn{5}{|l|}{ Financial Variables } \\
\hline netfixasset_equity & $\begin{array}{c}0,010 \\
(0,006)\end{array}$ & $\begin{array}{c}0,010 \\
(0,006)\end{array}$ & $\begin{array}{c}0,010 \\
(0,006)\end{array}$ & $\begin{array}{c}0,010 \\
(0,006)\end{array}$ \\
\hline ofcf_capex & $\begin{array}{c}0,000 \\
(0,000)\end{array}$ & $\begin{array}{c}0,000 \\
(0,000)\end{array}$ & $\begin{array}{c}0,000 \\
(0,000)\end{array}$ & $\begin{array}{c}0,000 \\
(0,000)\end{array}$ \\
\hline ebitda finexp & $\begin{array}{c}0,000 * * * \\
(0,000)\end{array}$ & $\begin{array}{c}0,000 * * * \\
(0,000)\end{array}$ & $\begin{array}{c}0,000^{* * * *} \\
(0,000)\end{array}$ & $\begin{array}{c}0,000 * * * \\
(0,000)\end{array}$ \\
\hline roa & $\begin{array}{c}-0,056^{* * *} \\
(0,017)\end{array}$ & $\begin{array}{c}-0,055^{* * * *} \\
(0,017)\end{array}$ & $\begin{array}{c}-0,054^{* * *} \\
(0,017)\end{array}$ & $\begin{array}{c}-0,053^{* * *} \\
(0,017)\end{array}$ \\
\hline book to $\mathrm{mkt}$ & $\begin{array}{c}0,000^{* * *} \\
(0,000)\end{array}$ & $\begin{array}{c}-0,001^{* *} \\
(0,000)\end{array}$ & $\begin{array}{c}0,000 * * \\
(0,000)\end{array}$ & $\begin{array}{c}-0,001 * * \\
(0,000)\end{array}$ \\
\hline size $m v \ln$ & $\begin{array}{c}-0,009^{* *} * \\
(0,004)\end{array}$ & $\begin{array}{c}-0,009^{* * * * *} \\
(0,004)\end{array}$ & $\begin{array}{c}-0,009^{* * *} \\
(0,004)\end{array}$ & $\begin{array}{c}-0,010^{*} \text { ***** } \\
(0,004)\end{array}$ \\
\hline size rev $\ln$ & $\begin{array}{c}0,009^{* * * *} \\
(0,002)\end{array}$ & $\begin{array}{c}0,009 * * * \\
(0,002)\end{array}$ & $\begin{array}{c}0,009^{* * *} \\
(0,002)\end{array}$ & $\begin{array}{c}0,009^{* * *} * \\
(0,002)\end{array}$ \\
\hline \multicolumn{5}{|l|}{ Focus variable } \\
\hline$p e$ & $\begin{array}{l}0,010^{*} \\
(0,006)\end{array}$ & $\begin{array}{l}0,053^{*} \\
(0,031)\end{array}$ & $\begin{array}{c}0,009 \\
(0,006)\end{array}$ & $\begin{array}{c}0,052 \\
(0,032)\end{array}$ \\
\hline \multicolumn{5}{|c|}{ Market insertion variables } \\
\hline$a d r$ & $\begin{array}{c}-0,057^{* * *} \\
(0,016)\end{array}$ & $\begin{array}{c}-0,072^{* * * *} \\
(0,020)\end{array}$ & $\begin{array}{c}-0,056^{* * *} \\
(0,016)\end{array}$ & $\begin{array}{c}-0,071^{* * * *} \\
(0,020)\end{array}$ \\
\hline $\mathrm{nm}$ & $\begin{array}{c}-0,034^{* *} \\
(0,017)\end{array}$ & $\begin{array}{l}-0,013 \\
(0,026)\end{array}$ & $\begin{array}{c}-0,034^{*} \\
(0,017)\end{array}$ & $\begin{array}{c}-0,013 \\
(0,026)\end{array}$ \\
\hline \multicolumn{5}{|c|}{ Market registration variables } \\
\hline industry & $\begin{array}{c}0,012 \\
(0,014)\end{array}$ & $\begin{array}{c}0,012 \\
(0,014)\end{array}$ & $\begin{array}{c}0,011 \\
(0,014)\end{array}$ & $\begin{array}{c}0,012 \\
(0,014)\end{array}$ \\
\hline utilities & $\begin{array}{c}-0,011 \\
(0,014)\end{array}$ & $\begin{array}{l}-0,017 \\
(0,013)\end{array}$ & $\begin{array}{l}-0,012 \\
(0,014)\end{array}$ & $\begin{array}{l}-0,018 \\
(0,013)\end{array}$ \\
\hline food & $\begin{array}{c}0,030 \\
(0,029)\end{array}$ & $\begin{array}{c}0,027 \\
(0,028)\end{array}$ & $\begin{array}{c}0,029 \\
(0,029)\end{array}$ & $\begin{array}{c}0,026 \\
(0,028)\end{array}$ \\
\hline retail & $\begin{array}{l}-0,005 \\
(0,007)\end{array}$ & $\begin{array}{l}-0,006 \\
(0,007)\end{array}$ & $\begin{array}{l}-0,006 \\
(0,007)\end{array}$ & $\begin{array}{l}-0,007 \\
(0,007)\end{array}$ \\
\hline construction & $\begin{array}{c}-0,038^{* * *} \\
(0,009)\end{array}$ & $\begin{array}{c}-0,040 * * * \\
(0,009)\end{array}$ & $\begin{array}{c}-0,039 * * * \\
(0,009)\end{array}$ & $\begin{array}{c}-0,040^{* * *} * \\
(0,009)\end{array}$ \\
\hline technology & $\begin{array}{c}-0,013 \\
(0,014)\end{array}$ & $\begin{array}{l}-0,013 \\
(0,014)\end{array}$ & $\begin{array}{l}-0,014 \\
(0,014)\end{array}$ & $\begin{array}{l}-0,014 \\
(0,014)\end{array}$ \\
\hline real estate & $\begin{array}{c}0,000 \\
(0,022)\end{array}$ & $\begin{array}{c}0,001 \\
(0,023)\end{array}$ & $\begin{array}{l}-0,001 \\
(0,022)\end{array}$ & $\begin{array}{c}0,001 \\
(0,023)\end{array}$ \\
\hline logistics & $\begin{array}{c}-0,043 * * * \\
(0,014)\end{array}$ & $\begin{array}{c}-0,038^{* * * *} \\
(0,014)\end{array}$ & $\begin{array}{c}-0,043 * * * \\
(0,014)\end{array}$ & $\begin{array}{c}-0,038 * * * \\
(0,014)\end{array}$ \\
\hline services & $\begin{array}{c}0,024 \\
(0,022)\end{array}$ & $\begin{array}{l}0,039^{*} \\
(0,021)\end{array}$ & $\begin{array}{c}0,024 \\
(0,022)\end{array}$ & $\begin{array}{l}0,038^{*} \\
(0,021)\end{array}$ \\
\hline \multicolumn{5}{|c|}{ Macroeconomic Circumstances } \\
\hline ipo boom & $\begin{array}{c}0,042^{* * * *} \\
(0,006)\end{array}$ & $\begin{array}{c}0,041 * * * * \\
(0,006)\end{array}$ & $\begin{array}{c}0,038^{* * * * *} \\
(0,007)\end{array}$ & $\begin{array}{c}0,037 * * * \\
(0,007)\end{array}$ \\
\hline crisis & $\begin{array}{c}0,045^{* * * *} \\
(0,007)\end{array}$ & $\begin{array}{c}0,045^{* * *} \\
(0,007)\end{array}$ & $\begin{array}{c}0,045^{* * * *} \\
(0,007)\end{array}$ & $\begin{array}{c}0,044 * * * * \\
(0,007)\end{array}$ \\
\hline \multicolumn{5}{|l|}{ Interacting effects } \\
\hline PE x New Market & & $\begin{array}{c}-0,048 \\
(0,036)\end{array}$ & & $\begin{array}{l}-0,048 \\
(0,036)\end{array}$ \\
\hline PE x IPO Boom years & & & $\begin{array}{c}0,009^{* * *} \\
(0,004)\end{array}$ & $\begin{array}{c}0,009 * * \\
(0,004)\end{array}$ \\
\hline Observations & 612 & 612 & 612 & 612 \\
\hline F-statistic & $9,967 * * *$ & $9,748^{* * *}$ & $9,547^{* * *}$ & $9,352 * * *$ \\
\hline R-squared & 0,262 & 0,267 & 0,263 & 0,268 \\
\hline Adjusted $\mathrm{R}^{2}$ & 0,236 & 0,240 & 0,235 & 0,239 \\
\hline$\Delta R^{2}$ & 0,120 & 0,004 & $-0,001$ & 0,003 \\
\hline
\end{tabular}


Other variables were tested in the estimation process, but were not included in the discussion. Size_asset_ln, netfxasset_totasset and ocf_ln are among such variables. The first of them demonstrated high correlation with size_mv_lnand size_rev_ln and was not considered in the final model. As for netfxasset_totassetand ofc_lntheir alternative variables, namely netfxasset_equityand ofcf_capex,generated better results and were thus preferred.

In order to check for the influence of lagged variables on WACC and to verify the behavior of the same variables in Brazilian Real, three additional models were estimated. Each model's specification is detailed below.

$W A C C=\beta_{0}+\beta_{1 i t-1}(\text { netfxasset_equity })_{i t-1}+\beta_{2 i t}\left(\right.$ ofcf_capex $_{i t-1}+\beta_{3 i t-}$ ${ }_{1}(\text { ebitda_finexp })_{i t-1}+\beta_{4 i t-1}(\text { netincome_roa })_{i t-1}+\beta_{5 i t-1}(\text { book_to_market })_{i t-1}+\beta_{6 i t-}$ ${ }_{1}(\text { size_mv_ln })_{i t-1}+\beta_{7 i t-1}(\text { size_rev_ln })_{i t-1}+\beta_{8 i t-1}(\text { pe })_{i t-1}+\beta_{9 i t-1}(a \overline{d r})_{i t-1}+\beta_{10 i t-1}(n m)_{i t-1}$

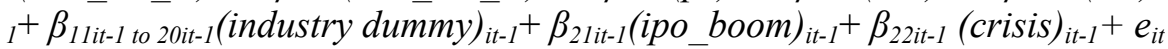

$W A C C=\beta_{0}+\beta_{\text {Iit }}(\text { netfxasset_equity })_{i t}+\beta_{2 i t}(\text { ofcf_capex })_{i t}+\beta_{3 i t}(\text { ebitda_finexp })_{i t}+$ $\beta_{4 i t}(\text { netincome_roa })_{i t}+\beta_{5 i t}(\text { book_to_market })_{i t}+\bar{\beta}_{6 i t}(\text { size_mv_ln })_{i t}+$ $\beta_{7 i t}(\text { size_rev_ln })_{i t}+\beta_{8 i t}(\text { pe })_{i t}+\beta_{9 i t}(a \overline{d r})_{i t}+\beta_{10 i t}(n m)_{i t}+\beta_{11 i t \text { to } 20 i t}(\text { industry dummy })_{i t}+$ $\beta_{21 i t}(\text { ipo_boom })_{i t}+\beta_{22 i t}(\text { crisis })_{i t}+e_{i t}$

$W A C C=\beta_{0}+\beta_{1 i t-1}(\text { netfxasset_equity })_{i t-1}+\beta_{2 i t}(\text { ofcf_capex })_{i t-1}+\beta_{3 i t-}$ ${ }_{1}(\text { ebitda_finexp })_{i t-1}+\beta_{4 i t-1}(\text { netincome_roa })_{i t-1}+\beta_{5 i t-1}(\text { book_to_market })_{i t-1}+\beta_{6 i t-}$ ${ }_{1}(\text { size_mv_ln })_{i t-1}+\beta_{7 i t-1}(\text { size_rev_ln })_{i t-1}+\beta_{8 i t-1}(p e)_{i t-1}+\beta_{9 i t-1}(a \overline{d r})_{i t-1}+\beta_{10 i t-1}(n m)_{i t-1}+\quad$ lagged $)$ $\beta_{\text {1lit-1 to 20it-1 }}(\text { industry dummy) })_{\text {it-1 }}+\beta_{2 \text { lit-1 }}(\text { ipo_boom })_{i t-1}+\beta_{22 i t-1}(\text { crisis })_{i t-1}+e_{i t}$

Results for each of the three additional models can be found in table 9 . The $8^{\text {th }}$ model was estimated, using a one period lag. This procedure could shed some light on possible delays between the financial and economic facts and their influence, through the many variables analyzed, on the cost of capital. Resulting estimates present some differences that are worth mentioning. Due to the introduction of time lag, this model uses 499 observations, against 612 used by the previous ones. However, one point in particular deserves mentioning: in this model the dummy for PE/VC presents no statistical significance, suggesting it does not influence the cost of capital for the following year. The same financial variables are significant, although at a lower level (ebitda_finexp, roaand book_to_mkt). One variable, size_mv_ln, is no longer significant, meaning the size of the company measured in terms of market value does not influence WACC of the following period. On the other hand, netfxasset_equityis significant at the 5\% 
level for the lagged model, suggesting the immobilization of capital raises WACC for the next period.

Using the same methodological procedures, further regression estimates were obtained with the data in its original currency (BRL), in order to certificate if the conclusions that resulted from the models in US dollars are maintained. Overall, the model in Brazilian Real loses explanatory power. While roais no longer significant, ebitda_finexpand size_rev_lnare now significant at the 10\% and 5\% levels, respectively. Three additional industry coefficients are significant, but the main variable, $p e$, is not.

Additional estimates were obtained for the model in Brazilian Real with the introduction of one period lag between the dependent and the explanatory variables. The time lagged model obtained in BRL presents marked differences when compared to model 8. From the group of financial variables, four (instead of five) variables are significant, most of which at the $10 \%$ level. Adrand $\mathrm{nm}$ are significant at the 1\% level with the expected sign and ipo_boomis significant but with a positive sign. Most important of all, peis not significant. This implies that the observed explanatory variables in one period do not seem to influence the cost of capital of the next period. 


\section{Tabel 9 - Estimated regression in Brazilian Real and lag}

D.V.: Dependent variable. Independent variables: 1) Net Fixed Asset ratio 2: ratio between total fixed asset and equity (for USD) or total asset (for BRL); 2) Operating Free Cash Flow over CAPEX: ratio between operating cash flow and amount dedicated to CAPEX OR Logarithm of Operating Cash flow for BRL; 3) EBITDA over Financial Expenses: total EBITDA of the exercise divided by the amount of financial expenses; 4) ROA: Net income divided by total asset; 5) Book to Market: book value of equity divided by market value of equity; 6) Market Capitalization: logarithm of total volume of outstanding shares multiplied by the stock price of each period; 7) Size of Revenue: logarithm of total net revenue earned in a fiscal year; 8) Private Equity: dummy that assumes the value of one if PE/VC among shareholders and 0 otherwise; 9) ADR: dummy that assumes the value of 1 if company has ADR or 0 otherwise; 10) New Market: dummy that assumes the value of 1 if company is part of Bovespa's New Market or 0 otherwise; 11 to 19: dummy introduced for each type of industry that company belongs to, assuming the value of 1 if the company belongs to a specific industry or 0 otherwise; 20) IPO Boom years: dummy that assumes the value of 1 if financial information refers to 2006 or 2007 and 0 otherwise; 21) Crisis year: dummy that assumes the value of 1 if financial information refer to 2008 or the value of 0 otherwise.

All coefficients are obtained by estimating random-effects panel data model. Industry dummies are included in each regression but are not reported. Data include yearly information for 129 companies from 2004 to 2013. Heteroskedasticity consistent standard errors clustered are reported in parentheses. *, **, and *** represent statistical significance at the $10 \%$ $5 \%$, and $1 \%$ level, respectively.Source: data analysis.

\begin{tabular}{|c|c|c|c|c|}
\hline \multicolumn{5}{|c|}{ D.V.: Weighted average cost of capital } \\
\hline Coefficients & Model 7 & Model 8 & BRL & BRL (lagged) \\
\hline Constant & $\begin{array}{l}0,142^{*} \\
(0,077)\end{array}$ & $\begin{array}{l}0,139^{* * *} \\
(0,068)\end{array}$ & $\begin{array}{c}0,253^{* * * *} \\
(0,082)\end{array}$ & $\begin{array}{c}0,191 * * * \\
(0,073)\end{array}$ \\
\hline \multicolumn{5}{|c|}{ Explanatory variables } \\
\hline \multicolumn{5}{|c|}{ Financial Variables } \\
\hline netfxasset_equity & $\begin{array}{c}0,010 \\
(0,006)\end{array}$ & $\begin{array}{l}0,007 * * \\
(0,003)\end{array}$ & $\begin{array}{c}0,008 \\
(0,007)\end{array}$ & $\begin{array}{c}0,002 \\
(0,004)\end{array}$ \\
\hline ofcf_capex & $\begin{array}{c}0,000 \\
(0,000)\end{array}$ & $\begin{array}{c}0,000 \\
(0,000)\end{array}$ & $\begin{array}{c}0,000 \\
(0,000)\end{array}$ & $\begin{array}{c}0,000 \\
(0,000)\end{array}$ \\
\hline ebitda_finexp & $\begin{array}{c}0,000^{* * * *} \\
(0,000)\end{array}$ & $\begin{array}{l}0,000 * * \\
(0,000)\end{array}$ & $\begin{array}{l}0,000^{*} \\
(0,000)\end{array}$ & $\begin{array}{c}0,000 \\
(0,000)\end{array}$ \\
\hline roa & $\begin{array}{c}-0,056^{* * * *} \\
(0,017)\end{array}$ & $\begin{array}{c}-0,126^{* *} \\
(0,063)\end{array}$ & $\begin{array}{l}-0,013 \\
(0,027)\end{array}$ & $\begin{array}{c}-0,116^{*} \\
(0,059)\end{array}$ \\
\hline book to $\mathrm{mkt}$ & $\begin{array}{c}0,000^{* *} \\
(0,000)\end{array}$ & $\begin{array}{l}0,000^{*} \\
(0,000)\end{array}$ & $\begin{array}{c}-0,001^{* *} * \\
(0,000)\end{array}$ & $\begin{array}{l}0,000^{*} \\
(0,000)\end{array}$ \\
\hline size $m v \ln$ & $\begin{array}{c}-0,009^{* *} \\
(0,004)\end{array}$ & $\begin{array}{c}-0,005 \\
(0,003)\end{array}$ & $\begin{array}{c}-0,009 * * \\
(0,004)\end{array}$ & $\begin{array}{c}-0,006^{*} \\
(0,003)\end{array}$ \\
\hline size rev $\ln$ & $\begin{array}{c}0,009 * * * \\
(0,002)\end{array}$ & $\begin{array}{c}0,007 * * * \\
(0,002)\end{array}$ & $\begin{array}{c}0,005 * * \\
(0,002)\end{array}$ & $\begin{array}{c}0,006 * * \\
(0,003)\end{array}$ \\
\hline \multicolumn{5}{|l|}{ Focus variable } \\
\hline$p e$ & $\begin{array}{l}0,010^{*} \\
(0,006)\end{array}$ & $\begin{array}{c}-0,001 \\
(0,008)\end{array}$ & $\begin{array}{c}0,002 \\
(0,005)\end{array}$ & $\begin{array}{c}-0,003 \\
(0,008)\end{array}$ \\
\hline \multicolumn{5}{|c|}{ Market insertion va } \\
\hline$a d r$ & $\begin{array}{c}-0,057^{* * * *} \\
(0,016)\end{array}$ & $\begin{array}{c}-0,052^{* * * *} \\
(0,012)\end{array}$ & $\begin{array}{c}-0,048^{* * * *} \\
(0,016)\end{array}$ & $\begin{array}{c}-0,047^{* * * *} \\
(0,011)\end{array}$ \\
\hline$n m$ & $\begin{array}{c}-0,034^{* *} \\
(0,017)\end{array}$ & $\begin{array}{c}-0,043^{* * * *} \\
(0,012)\end{array}$ & $\begin{array}{c}-0,043^{* * *} \\
(0,016)\end{array}$ & $\begin{array}{c}-0,043^{* * * *} \\
(0,008)\end{array}$ \\
\hline \multicolumn{5}{|c|}{ Market registration } \\
\hline industry & $\begin{array}{c}0,012 \\
(0,014)\end{array}$ & $\begin{array}{c}0,017 \\
(0,011)\end{array}$ & $\begin{array}{c}0,003 \\
(0,009)\end{array}$ & $\begin{array}{c}0,006 \\
(0,014)\end{array}$ \\
\hline utilities & $\begin{array}{c}-0,011 \\
(0,014)\end{array}$ & $\begin{array}{c}-0,011 \\
(0,016)\end{array}$ & $\begin{array}{c}-0,024 \\
(0,015)\end{array}$ & $\begin{array}{c}-0,024 \\
(0,022)\end{array}$ \\
\hline food & $\begin{array}{c}0,030 \\
(0,029)\end{array}$ & $\begin{array}{c}0,022 \\
(0,021)\end{array}$ & $\begin{array}{c}0,015 \\
(0,027)\end{array}$ & $\begin{array}{c}0,011 \\
(0,026)\end{array}$ \\
\hline retail & $\begin{array}{l}-0,005 \\
(0,007)\end{array}$ & $\begin{array}{l}-0,003 \\
(0,011)\end{array}$ & $\begin{array}{c}-0,012 * * \\
(0,006)\end{array}$ & $\begin{array}{c}-0,018 \\
(0,012)\end{array}$ \\
\hline construction & $\begin{array}{c}-0,038^{* * * *} \\
(0,009)\end{array}$ & $\begin{array}{c}-0,040^{* * * *} \\
(0,010)\end{array}$ & $\begin{array}{c}-0,054^{* * * *} \\
(0,005)\end{array}$ & $\begin{array}{c}-0,058^{* * * * *} \\
(0,014)\end{array}$ \\
\hline technology & $\begin{array}{l}-0,013 \\
(0,014)\end{array}$ & $\begin{array}{c}-0,006 \\
(0,012)\end{array}$ & $\begin{array}{c}-0,021^{*} \\
(0,012)\end{array}$ & $\begin{array}{c}-0,015 \\
(0,018)\end{array}$ \\
\hline real estate & $\begin{array}{c}0,000 \\
(0,022)\end{array}$ & $\begin{array}{c}0,013 \\
(0,019)\end{array}$ & $\begin{array}{l}-0,015 \\
(0,014)\end{array}$ & $\begin{array}{c}0,001 \\
(0,021)\end{array}$ \\
\hline logistics & $\begin{array}{c}-0,043^{* * * *} \\
(0,014)\end{array}$ & $\begin{array}{c}-0,044^{* * * *} \\
(0,017)\end{array}$ & $\begin{array}{c}-0,063^{* * *} * \\
(0,013)\end{array}$ & $\begin{array}{c}-0,054^{* * * *} \\
(0,018)\end{array}$ \\
\hline services & $\begin{array}{c}0,024 \\
(0,022)\end{array}$ & $\begin{array}{c}-0,014 \\
(0,018)\end{array}$ & $\begin{array}{c}-0,029 * * * \\
(0,007)\end{array}$ & $\begin{array}{c}-0,031 \\
(0,019)\end{array}$ \\
\hline \multicolumn{5}{|c|}{ Macroeconomic Cir } \\
\hline ipo boom & $\begin{array}{c}0,042^{* * * *} \\
(0,006)\end{array}$ & $\begin{array}{c}0,056^{* * * *} \\
(0,016)\end{array}$ & $\begin{array}{l}0,018 * * \\
(0,008)\end{array}$ & $\begin{array}{c}0,036^{* * * *} \\
(0,012)\end{array}$ \\
\hline crisis & $\begin{array}{c}0,045^{* * * *} \\
(0,007)\end{array}$ & $\begin{array}{l}-0,016^{*} \\
(0,008)\end{array}$ & $\begin{array}{c}0,026 * * * \\
(0,007)\end{array}$ & $\begin{array}{l}-0,010 \\
(0,007)\end{array}$ \\
\hline Observations & 612 & 499 & 602 & 489 \\
\hline F-statistic & $9,967 * * *$ & $6,644 * * *$ & $6,430^{* * * *}$ & $5,026 * * *$ \\
\hline R-squared & 0,262 & 0,226 & 0,189 & 0,184 \\
\hline Adjusted $\mathrm{R}^{2}$ & 0,236 & 0,192 & 0,159 & 0,148 \\
\hline$\Delta \mathrm{R}^{2}$ & 0,120 & $-0,044$ & $-0,077$ & $-0,088$ \\
\hline
\end{tabular}


Other tests were performed with results that are worth mentioning. Since model 7 results suggest a positive and significant coefficient for $p e$, a few attempts were made to estimate the difference of cost of capital between invested and noninvested companies. The t-statistic was used to invesgate such difference but results suggested no difference of the average cost of capital between invested and non-invested companies.

Additionally, it is possible that the choice of variables and the order they were introduced in each model does not represent an optimal choice. For that matter a Stepwise procedure was applied. Despite the high overall adjusted $\mathrm{R}^{2}$, following previous results, the coefficient of the focus variable pewas not significant at any level.

Given the hypothesis that cost of equity and cost of debt could have different and divergent impacts on cost of capital, additional regression analysis considered each one separately, as the dependent variable. The level of adjusted $\mathrm{R}^{2}$ differed greatly between the two dependent variables. While adjusted $\mathrm{R}^{2}$ for cost of debt as the dependent variable was around 0,10 , for cost of equity it was interestingly higher, close to 0,70 . Nevertheless, both regressions resulted in no significant coefficient for $p e$. 


\section{Conclusions}

The dependent variable estimated in this study was the weighted average cost of capital, calculated with the CAPM model for the cost of equity and average measures of financial expenses over debt for the total cost of debt. For the explanatory variables, except for the industry variables and two financial variables introduced in the estimated models, all other variables introduced were significant, despite the fact that five signs obtained were opposite to what was expected. Logarithm of net revenuewill increase the cost of capital at the $1 \%$ level of significance. This variable probably influences the perception of efficiency and growth capacity the market has on the company's activity.

IPO boom years, as well as the crisis year also increase the cost of capital, possibly due to divergent reasons. While the boom years might have increased the cost of capital because of higher returns, the crisis year of 2008 might have increased it on the debt share of the cost of capital.

On the other hand, return measures such as return on asset, as well as Market Capitalization will reduce the cost of capital. These variables will probably impact the equity share of the cost of capital, but it is also possible that, representing measures of capacity to generate cash, they can negatively influence cost of debt.

The form with which the company relates to the market also reduces the cost of capital, be it through its presence in foreign markets or through improving the corporate governance structure. Either way, the perceived risk tends to be smaller.

The fact that only two out of ten industry dummies were significant may suggest that other factors have higher influence on the cost of capital. It could be suggested that the number of companies in each industry may have influenced their significance in the model, since both construction and logistics are among the most numerous. In that sense, it may advisable to use other forms grouping the sampled companies.

Apart from individual influences of a company's financial variables, capital costs should reflect current market conditions and costs should equal the investor's 
anticipated rate of return on future cash flows associated with each form of capital (BRUNER et al., 1998). Given that firms face different costs for different sources of financing, in order to try and maximize stockholders' utility and return, it should follow that they will use the least expensive source first (AUERBACH, 1984; HUANG; RITTER, 2009). For many cases, issuing shares bears a significant cost and thus should be the last option, especially when capital structure decisions have long lasting effects over returns and market value. In that sense, it also seems reasonable that firms will issue shares when its relative cost is low (HUANG; RITTER, 2009; ALBANEZ, 2012).

Consistent with the issue of relative cost of each source of capital, the regression models tested in this work suggest that companies invested by $\mathrm{PE} / \mathrm{VC}$ funds will face higher cost of capital. The dummy variable introduced to account for PE/VC investment is significant at the $10 \%$ level and positively correlated with the dependent variable, weighted average cost of capital. A priori, the expected sign for this coefficient was uncertain, given that $\mathrm{PE} / \mathrm{VC}$ participation among shareholders contributes to the company's relationship with both credit and stock market, tending to reduce the overall cost a company incurs when looking for financing. The resulting positive sign, however, suggests this could have a significant impact in terms of cost of capital analysis and managing decisions. When looking for financing sources, a financial manager's goal should be more directed to minimizing the cost of debt, instead of the overall cost of capital. The relationship with financial institutions must be dealt with in terms of further reducing information asymmetry, assuring return and mitigating the range of perceived risks.

More funding options need to be taken into account and a whole set of approaches needs to be developed in order to implement good relationships with alternative private funding sources. Contrary to the terms established with financial institutions, focused on minimizing cost, such alternative relationships should address opportunities for maximizing returns.

Results obtained in this study find support among a number of other studies (PHAM et al., 2007; BOZEC,Y.; BOZEC, R., 2010; ALBANEZ, 2012;). The debt share of the cost of capital tends to be smaller for companies with a good 
corporate governance structure and their leverage is positively correlated with the cost of equity. Since the dummy introduced for PE/VC in the estimated models is significant, we can infer that, holding other variables constant, any improve in corporate governance reduces the cost of debt. The entrance of $\mathrm{PE} / \mathrm{VC}$ funds as stakeholders reduces the cost of debt by improving invested companies corporate governance and simultaneously increases the return on equity.

Since IPO's constitute one of the main exit strategies for investments, exit through IPO and the willingness of investors to finance the PE/VC industry depends on well-developed stock market as a condition for the existence of a developed PE/VC industry (GILSON; BLACK, 1999; COMODO, 2009). Such development might also influence the overall credit marketand the economy as well. When such exit option is available, $\mathrm{PE} / \mathrm{VC}$ becomes an alternative source of funding that competes with the credit market. From the standpoint of invested companies, the amount received from $\mathrm{PE} / \mathrm{VC}$ is a long term source of funds with no interest or amortization payment, as well as no collateral, as demanded by traditional sources of capital. From the investor standpoint, however, it represents a low liquidity, highly risky opportunity that demands a great deal of scrutiny in order to be approved (TESTA; LIMA, 2013). The higher the stimulus and willingness of $\mathrm{PE} / \mathrm{VC}$ funds to invest, the more competitive it is, forcing the overall credit market to adjust its lending spread and thus, reducing the cost of debt (GILSON; BLACK, 1999; RIBEIRO, 2005; TESTA; LIMA,2013).

The significance of the PE/VC dummy variable and its positive sign also find support among the studies that focused on the performance improvements of invested companies (GORMAN; SAHLMAN, 1987; UCHIMURA, 2011; ELLER, 2012; BOTTAI, 2013; TESTA; LIMA, 2013). Higher returns derive from $\mathrm{PE} / \mathrm{VC}$ funds' influence on performance and market evaluation, explaining the higher return on equity and, to some extent, higher overall cost of capital.

However positive this may seem, it holds a relative downside, in which a company's long term investment plans will be more severe due to higher discount rates in the presence of $\mathrm{PE} / \mathrm{VC}$ funds. In other words, investment projects will need to be more profitable. Although this means investments will have greater returns, it more strictly limits the range of investment possibilities. All in all, the 
presence of $\mathrm{PE} / \mathrm{VC}$ funds among shareholders increases the number of interested parties and, as a consequence, it increases the complexity of agency conflicts that must be addressed within a company's boundaries. The upside from all of this may be that companies tend to become more competitive, more profitable and long lasting.

Despite the lack of statistical significance of the dummy variable pe in the model in Brazilian Real, the fact that peis significant at the $10 \%$ level for the model in US dollars may be due to differences in the behavior of the market from which information was used. Since the Brazilian market is much more concentrated on a small number of companies, it may be the case that such companies influence the market, and hence the beta estimates. In that case, any model may produce results that diverge from a model that considers a bigger number of players, like that represented by the S\&P 500 index. Also, the introduction of a risk measure for the model in US dollars may incorporate circumstantial events that interfere not only to the dynamics of the market in a fiscal year but also with the mechanisms that enable influence of one period into the next.

The literature raised on the subject of this study did not indicate any previous analysis of $\mathrm{PE} / \mathrm{VC}$ impact on cost of capital. Moreover, no quantitative study frame integrating cost of capital and PE/VC theories has been identified. In that sense, the model estimated and the results obtained can provide some understanding of the relationship between these two variables, enabling further analysis that will contribute to strategically address corporate cost of capital and financing issues. 


\section{Opportunities for further investigation}

The conclusions withdrawn from this study suggest further analysis should be carried out to identify how the studied variables influence each share of the cost of capital, individually. Even more, it should be applied to different samples in other markets with data from different periods in order to verify if the same conclusions hold. This could further clarify why the presence of PE/VC funds increases cost of capital in two different ways. First, it could address the variables effects to either the equity or debt share. Second it could certify whether the results only apply to the Brazilian market and to the period considered in the sample.

In this study CAPM was used as the equity cost, since its use is widely recommended and unanimous. Other proxies for cost of equity could be used, as well as for cost of debt, namely the rating criteria, as in Albanez (2012). Given the result obtained for the $\mathrm{PE} / \mathrm{VC}$ dummy introduced in this study, it is possible that $\mathrm{PE} / \mathrm{VC}$ produces distinct impacts over each type of cost. Analysis could be conducted to verify whether the effect on cost of equity alone is positive, resulting from the increase in the return on equity. In the opposite direction, it should be confirmed whether $\mathrm{PE} / \mathrm{VC}$ reduces cost of debt, considered alone. Further variables might be necessary to address these issues separately.

Further, accepting that a manager's goal should more objectively address the cost of debt, additional variables need to be identified and included in a model that explains the cost of debt. Such incursion can provide more direct measures that could be used daily for managerial practices in their relationship with financial institutions.

Finally, since this study focused the Brazilian stock market, the use of information from different economies could shed light on how PE/VC impacts companies cost of capital in those markets. 


\section{References}

ALBANEZ, T. O.; LIMA, G. Efeitos do Market Timing sobre a Estrutura de Capital de Companhias abertas Brasileiras. Tese de Doutorado apresentada ao Departamento de Contabilidade e Atuária da Faculdade de Economia, Administração e Contabilidade da Universidade de São Paulo. São Paulo, 2012.

ARGOLO, E. F. B.; LEAL, R. P. C.; ALMEIDA, V. S. O modelo de Fama e French é aplicável no Brasil?. Rio de Janeiro: Instituto Coppead de Administração, 2012 (Relatório de Pesquisa)

AUERBACH, A. Taxes and Firm Financial Policy. Journal of Public Economics, Vol. 23.1984

BASSO, L.; MENDES, E.; KAYO, E. Estrutura de Capital e Janelas de Oportunidade: Testes no Mercado Brasileiro. Revista de Administração Mckenzie, v. 10, n. 6, p. 78-100, 2009

BASTOS, R. M. P. Desempenho pós-IPO de empresas investidas por Private Equity no Brasil: uma abordagem setorial. 2014. 75 p. Dissertação (Mestrado em Administração de Empresas). Universidade Católica do Rio de Janeiro, Departamento de Administração. Rio de Janeiro, 2014.

BOZEC, Y.; BOZEC, R. Overall Governance and Cost of Capital: Evidence from Canada Using Panel Data. Journal of Global Business Management6 (1): 1-11. 2010

BOTTAI, D. O impacto dos fundos de Private Equity no underpricing dos IPOs brasileiros. 2013. 32 p. Dissertação (Mestrado) - Insper Instituto de Ensino e Pesquisa, São Paulo, 2013

BRAV, A.; GOMPERS, P. Mythor Reality? The Long-Run Underperformance of Initial Public offerings: Evidence from Venture and NonVenture Capital-Backed Companies. The Journal of Finance, Vol. 52, № 5 (Dec. 1997), pp. 1791-1821

BROOKS, C. Introductory Econometrics for Finance. $2^{\text {nd }}$ edition.Cambridge, 2008.

BRUNER, R.; EADES, K.; HARRIS, R.; HIGGINS, R. Best Practices in Estimating the Cost of Capital: Survey and Synthesis. Financial Practice and Education - Spring/Summer 1998

CANELLAS, T. C.; LEAL, R. P. C. Evolução da Estrutura de Controle das Empresas Listadas na BOVESPA entre 2004 e 2006. Rio de Janeiro: Relatórios COPPEAD, 2010 (Relatório de Pesquisa)

CASOTTI, F.; MOTTA, L. Oferta Pública Inicial no Brasil (2004-2006): Uma abordagem da avaliação através de Múltiplos e do Custo de Capital Próprio. RevistaBrasileira de Finanças, 2008, Vol. 6, N 2, pp. 157-204.

COMODO, G. Uma análise Comparativa entre as Estruturas de Private Equity e Venture Capital nos EUA e no Brasil. 2009. Dissertação (Mestrado) Fundação Getúlio Vargas. São Paulo, 2009. 
CUNHA, M. et al. Custo de Capital Médio Ponderado na Avaliação de Empresas no Brasil: Uma investigação da aderência acadêmica e a prática de mercado. Revista Ambiente Contábil - UFRN - Natal-RN. Vol. 5, n. 2, p. 20-36. Jul/dez.2013

ELLER, E. P. Análise do desempenho de longo prazo dos IPOs de empresas com participação prévia de fundos de Private Equity e Ventura Capital de 2004 a 2011 na BMF \&Bovespa. 2012. 45 p. Dissertação (Mestrado) Fundação Getúlio Vargas, São Paulo, 2012.

GARBRECHT, G. Governança Corporativa e Custo de Capital: um estudo em empresas de capital aberto no Brasil. Dissertação (Mestrado) Universidade Federal do Paraná. Curitiba, 2013.

GILSON, R.; BALCK, B. Does Venture Capital Require na Active Stock Market? JournalofApplied Corporate Finance 36-48 (winter 1999).

GIOIELLI, S. Os gestores de Private Equity e Venture Capital influenciam a governança corporativa das investidas? Evidências das empresas estreantes na BOVESPA. Dissertação de Mestrado apresentada à escola de Administração de Empresas de São Paulo da Fundação Getúlio Vargas. São Paulo, 2008

GIOIELLI, S. Impactos do Investimento de PE/VC. GV-executivo, v. 7, n. 4, jul-ago, 2008.

GIOIELli, S.; CARVAlHO, A.; SAMPAIO, J. Capital de Risco e Gerenciamento de Resultados em IPO's. Brazilian Business Review, Vol. 10, n. 4. 2013 , p. $32-68$

GOMPERS, P.; LERNER, J. The Venture Capital Revolution. The Journal of Economic Perspectives, Vol. 15, No. 2 (Spring, 2001), pp. 145-168

GOMPERS, P. A,; KAPLAN, S. N.; MUKHARLYAMOV, V. What do Private Equity Firms (say they) do? Preliminary text. February 2014. Available at http://papers.ssrn.com/sol3/papers.cfm?abstract_id=2447605

GORMAN, M.; SAHLAMN, W. What do Venture Capitalists do? Harvard Business School notes. September 1, 1987 (9-288-015)

GUJARATI, D. N. Econometria Básica - Terceira Edição. São Paulo, 2000.

HELlMANN, T.; PURI, M. The Interaction between Product Market and Financing Strategy: the role of Venture Capital. The Review of Financial Studies, Winter 2000 Vol. 13, No. 4, pp. 959-984.

Venture Capital and the Professionalization of Start-Up firms: Empirical Evidence. The Journal of Finance, Vol. LVII, nº 1, Feb. 2002

On the Fundamental Role of Venture Capital.Federal Reserve Bank of Atlanta Economic Review, Fourth Quarter 2002 (2)

HUANG, R.; RITTER, J. Testing Theories of Capital Structure and Estimating the Speed of Adjustment. Journal of Financial and Quantitative Analysis, Vol. $44, \mathrm{~N}^{\mathrm{o}} 2$, Apr. 2009, pp. 237-271 
KPMG and ABVCAP. Consolidação de Dados da Indústria de Private Equity e Venture Capital no Brasil 2011/2012/2013. Research, 2014. Available at http://www.abvcap.com.br/Download/Estudos/2716.pdf

LAMBERT, R.; LEUZ, C.; VERRECCHIA, R. Information Assymetry, Information Precision, and the Cost of Capital. Review of Finance (2011) 16: 1 29

LEE, I.; LOCHHEAD, S.; RITTER, J.; ZHAO, Q. The Costs of Raising Capital.The Journal of Financial Research, Vol. XIX, No 1, Pages 59-74, Spring 1996

MINARDI, A. M. A. F.; FERRARI, G. L.; TAVARES, P. C. A.; Performances of Brazilian IPOs backed by Private Equity. Journal of Business Research 66 (2013) 448-455

MINARDI, A. M. A. F.; KANITZ, R. V.; BASSANI, R. H. ; Private Equity and Venture Capital Industry Performance in Brazil: 1990-2013. The Journal of Private Equity Vol. 16, N. . 4, Fall 2013

MODIGLIANI, F.; MILLER, M. The Cost of Capital, Corporation Finance and the Theory of Investment. The American Economic Review, Vol. XLVIII, June 1958 , N. 3

MOURA, R. FGV: capital comprometido por private equity crescerá 17\%. Fusões e Aquisições. 06/11/2014. Available at http://fusoesaquisicoes.blogspot. com.br/2014/11/fgvcapital-comprometido-por-private.html

OLIVEIRA, B.; MARTELANC, R. Determinantes do Cálculo do Custo Médio Ponderado de Capital no Brasil: um estudo empírico. XXXVII Encontro da ANPAD. Rio de Janeiro, 2013.

PAREJA, I.; BENAVIDES-FRANCO, J. Cost of Capital when Dividends are deductible. Revista Brasileira de Finanças, Rio de Janeiro, Vol. 9, $\mathrm{N}^{\mathbf{0}} 3$, September 2011, pp 309-334

PHAM, P.K.; SUCHARD, J. A.; J. ZEIN. "Corporate Governance, Cost of Capital and Performance: Evidence from Australian Firms." Working Paper available on the Social Science Research Network, Electronic Library athttp://unpan1.un.org/intradoc/groups/public/documents/APCITY/UNPAN03385 7.pdf. 2007.

RAMALHO, C. (org.); FURTADO, C. (org.); LARA, R. (org.). "A Indústria de Private Equity e Venture Capital - Segundo Censo Brasileiro". Brasília: ABDI - Agência Brasileira de Desenvolvimento Industrial, 2011

RIBEIRO, L. O Modelo Brasileiro de Private Equity e Venture Capital. 2005. 139 p. Dissertação (Mestrado em Administração de Empresas) Universidade de São Paulo. São Paulo, 2005.

SAHLMAN, W. A. The structure and governance of venture-capital organizations. Journal of Financial Economics 27 (1990) 473-521. NorthHolland. 
SILVA, A. R. Uso Generalizado de Stock Options e o Envolvimento de Fundos de Venture Capital e Private Equity: análise dos efeitos sobre o desempenho dos IPOs no Brasil. Dissertação (Mestrado) - Universidade Presbiteriana Mackenzie, São Paulo, 2014.

SIQUEIRA, E. et al. Determinantes do Sucesso dos Investimentos de Private Equity e Venture Capital no Brasil. Revista Brasileira de Finanças, Rio de Janeiro, Vol. 9, No 2, June 2011, pp. 189-208

TESTA, C.; LIMA, G. O Papel Certificador dos Fundos de Private Equity e Venture Capital na Qualidade das Empresas estreantes na BM\&F Bovespa. XXXVII Encontro da ANPAD. Rio de Janeiro, 2013.

UCHIMURA, E. I. Análise do desempenho de IPOs e Inovação: Estudo da Influência do Aporte de Fundos de PE/VC. 2011. 123 p. Dissertação (Administração de Empresas) Universidade Federal do Paraná. Curitiba, 2011 